\title{
From Top-Down to Bottom-Up Climate Policy: New Challenges in Carbon Market Design
}

\author{
JONAS MONAST*
}

TABLE OF CONTENTS

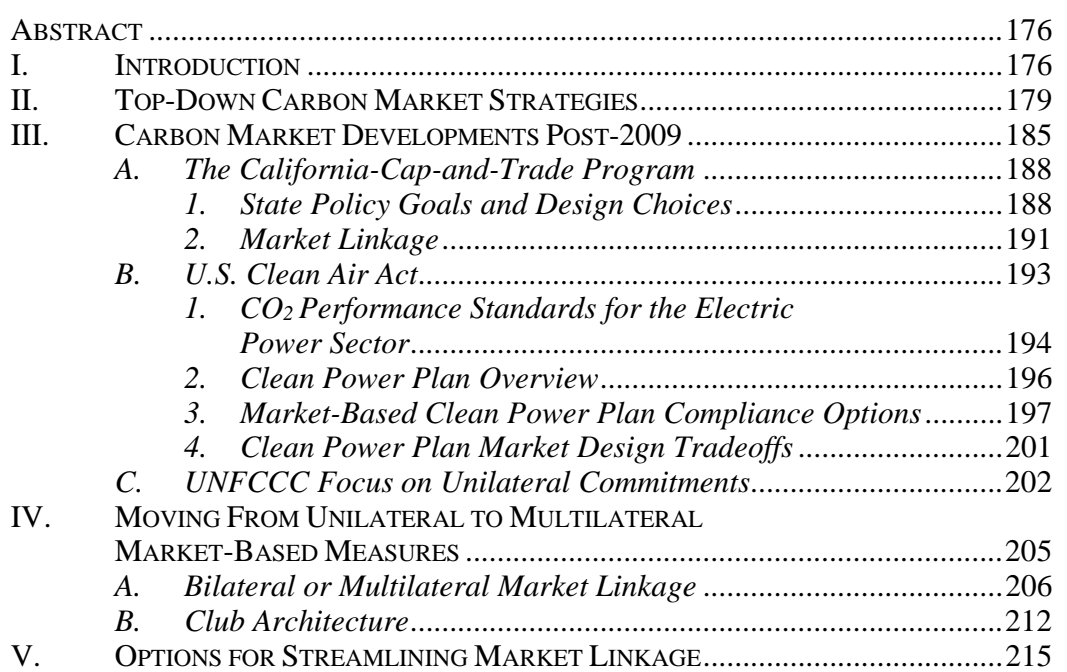

* (C) 2017 Jonas Monast. C. Boyden Gray Distinguished Fellow, Assistant Professor and Co-Director of the Center on Climate, Energy, Environmental \& Economics (CE3). J.D. 2002, Georgetown University; B.A. 1995, Appalachian State University. I am grateful to Victor Flatt, Jedediah Purdy, Joseph Blocher, Marin Levy, Matthew Adler, and the faculty of the University of North Carolina School of Law for providing feedback on early drafts of this Article. 


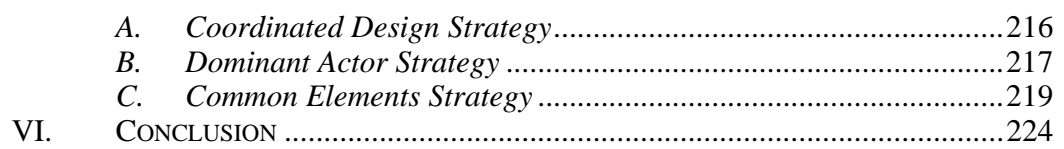

\begin{abstract}
The climate policy debate underwent a profound shift between 20092016. Prior to that point, efforts at the domestic and international levels focused on broad, top-down strategies to reduce greenhouse gas (GHG) emissions, with market-based mechanisms expected to play a key role. The simultaneous breakdown of the congressional climate policy debate and the failure of the United Nations Framework Convention on Climate Change (UNFCCC) to produce a new international agreement at the meeting in Copenhagen raised serious questions about the political viability of carbon markets, as well as the prospects for implementing meaningful near-term emission abatement strategies.

A number of bottom-up strategies have since emerged, including subnational experimentation with carbon market design, emissions trading options under the U.S. Environmental Protection Agency's Clean Power Plan, and the UNFCCC's focus on individual emission reduction commitments by member nations. These incremental steps represent important progress, but are incapable of stabilizing or reducing atmospheric GHG concentrations on their own. The ultimate success of the decentralized mitigation approaches currently underway, therefore, depends upon their ability to foster broader action.

This Article explores the shift from top-down to bottom-up approaches to carbon market design, focusing on three strategies that have emerged since 2009: the California Cap-and-Trade Program, the Clean Power Plan, and the UNFCCC process. The Article then examines the prospects for broad multilateral markets to emerge under a bottom-up approach and identifies three pathways to streamline market design choices: a coordinated approach; a dominant actor approach; and a common elements approach.
\end{abstract}

\title{
I. INTRODUCTION
}

The climate policy debate underwent a profound shift between 20092016. Prior to that point, efforts at the domestic and international levels focused on broad, top-down strategies to reduce greenhouse gas (GHG) emissions, with market-based mechanisms expected to play a key role. The U.S. House of Representatives adopted a bill establishing an economywide cap-and-trade program and negotiations through the United Nations Framework Convention on Climate Change (UNFCCC) process were 
building toward a new international agreement to limit global emissions. The simultaneous breakdown of the congressional climate policy debate and the failure of the UNFCCC negotiations to produce a new international agreement at the 2009 Conference of Parties (COP) in Copenhagen raised serious questions about the political viability of carbon markets, as well as the prospects for implementing meaningful near-term emission abatement strategies.

Despite the environmental, economic, and political successes of emissions trading in other contexts, these challenges proved insurmountable for U.S. lawmakers and UNFCCC negotiators in 2009-2010. Efforts to develop centralized policy platforms to foster the development of these market approaches stalled at both the national and international levels around roughly the same time due to the overarching political economy question of who bears the costs and who reaps the benefits of a legally-binding emission reduction requirement. ${ }^{1}$ Progress was also stifled by disagreement over emissions targets, concerns about competitiveness impacts for certain nations, states, and industrial sectors, and the sheer size and complexity of programs. ${ }^{2}$

The fate of market-based policies has waxed and waned since that time. While U.S. policymakers have shied away from broad federal legislation and international negotiators have shifted away from a uniform, legallybinding international agreement to tackle climate change, several new approaches have since emerged. Some subnational governments are unilaterally implementing market-based climate policies and experimenting with marketlinkage. In the U.S., the promulgation of the Clean Power Plan-a rule issued pursuant to the Clean Air Act that establishes state-by-state carbon dioxide $\left(\mathrm{CO}_{2}\right)$ emission limits for the nation's fleet of existing fossil fuelfired power plants - spurred renewed attention on market-based emission reduction strategies. ${ }^{3}$ This regulatory approach shifted the domestic climate policy debate from whether to regulate electric power sector emissions to

1. Jim Rossi, The Political Economy of Energy and Its Implications for Climate Change Legislation, 84 TuL. L. REV. 379 (2009).

2. This Article does not go into a full post-mortem analysis of the domestic and UNFCCC climate policy negotiations. For information about the domestic climate policy debate, see Eric Pooley, The Climate War: True Believers, Power Brokers, and the Fight TO SAVE THE EARTH (2010).

3. The fate of the Clean Power Plan is uncertain as this article goes to publication. President Trump signed an executive order on March 28, 2017 instructing the EPA to repeal the rule. Executive Order: Promoting Energy Independence and Economic Growth, Mar. 28, 2017, https://www.whitehouse.gov/the-press-office/2017/03/28/presidentialexecutive-order-promoting-energy-independence-and-economi-1. 
how to regulate. International efforts to mitigate climate change have similarly shifted to a bottom-up approach. The UNFCCC process is now focused on individual emission reduction pledges by member nations, with the prospect of linked markets emerging as nations seek options to meet their commitments.

The movement away from centralized, comprehensive emission abatement strategies to bottom-up approaches has important implications for climate policy. Incremental steps by national and subnational actors are incapable of stabilizing or reducing atmospheric GHG concentrations on their own. Thus, the success of the decentralized mitigation approaches currently underway will turn on whether they foster broader action.

The Article uses the term "top-down" to describe a uniform set of legally enforceable rules governing GHG reductions in multiple national or subnational jurisdictions. The top-down approach may occur via national rules governing emission reductions across the country or an international framework governing emission reductions by nations subject to the agreement. The federal Waxman-Markey climate bill is an example of a pure top-down market approach, as it aimed to establish an emissions cap for the nation's electric power national emission limitation, created a compliance-based emissions market, and specified the rules governing the market. This Article employs the term "bottom-up" to refer to decisions made by individual jurisdictions leading to a multilateral approach involving numerous nations or subnational jurisdictions, such as the Regional Greenhouse Gas Initiative, a multistate carbon market operating in the Northeastern and Mid-Atlantic U.S., and the linked carbon market between California and Quebec.

These descriptors are not absolute, as a top-down approach may still depend on decisions by individual actors regarding how to meet their obligations. For example, although the Kyoto Protocol is generally referred to as a top-down strategy, and meets the definition offered here, in practice it is a combination of top-down and bottom-up decision making. The agreement included emission reduction commitments by developed countries that were parties to the agreement and established market mechanisms that could contribute to meeting those obligations. ${ }^{4}$ It was up to the Annex I countries to determine whether and how to utilize these mechanisms, such as the EU decision to allow Kyoto Protocol-based emission reduction credits to qualify as compliance instruments within the EU Emissions Trading Scheme (EU ETS). ${ }^{5}$ Similarly, the California Cap-and-Trade Program is the result of a deliberate set of policy choices on the part of the state's

4. U.N. Framework Convention on Climate Change, Kyoto Protocol, U.N. Doc. FCCC/CP/1997/7/Add. 1 (Mar. 25, 1997).

5. Council Directive 2003/87/EC, preamble, para. 4, 2003 O.J. (L 275) (EC). 
government officials, but is treated as an example of a "bottom-up" climate policy in this article due to California's efforts to broaden the market to include additional jurisdictions.

Carbon markets and the prospect of market linkage offer the potential to build upon diffuse decision making by individual national and subnational actors. Linking is not an automatic option, however. Political compromises and financial investments based on initial market design choices shift the political economy considerations. The viability of bottom-up market linkage may depend on deliberate steps during the policy design process to facilitate market linkage in the future.

This Article begins by describing recent top-down approaches to climate policy and carbon market design included in the Waxman-Markey bill in the U.S. House of Representatives and the efforts to achieve a unified, legally-binding agreement through the UNFCCC process. It then discusses the breakdown of policy debates at both levels and the renewed prospects for carbon market implementation through three strategies that have emerged since 2009: the California Cap-and-Trade Program, the Clean Power Plan, and the UNFCCC process. The Article concludes by examining the prospects for broad multilateral markets to emerge under a bottom-up approach and identifying three pathways to streamline market design choices: a coordinated approach, a dominant actor approach, and a common elements approach.

\section{TOP-DOWN CARBON MARKET STRATEGIES}

Climate change presents perhaps the most vexing global commons problem. Greenhouse gas (GHG) emissions are globally-mixing pollutants, with emissions occurring anywhere across the globe resulting in the same cumulative impact on atmospheric concentrations. ${ }^{6}$ Reductions in one jurisdiction will not address the global commons problem if other jurisdictions increase their emissions by an equal or greater amount. ${ }^{7}$ Mitigating climate change, therefore, requires emission reduction efforts by numerous high

6. See Climate Change Indicators: Greenhouse Gases, U.S. ENVTL. PROTECTION AGENCY, https://www.epa.gov/climate-indicators/greenhouse-gases [https://perma.cc/UMF2EDZB] (last updated Feb. 22, 2016).

7. See id.; see also Issue Brief: The Global Climate Change Regime: Scope of the Challenge, COUNCIL ON FOREIGN REL., http://www.cfr.org/climate-change/global-climatechange-regime/p21831[https://perma.cc/2LYN-E55D] (last updated June 19, 2013) ("Fifteen to twenty countries are responsible for roughly 75 percent of global emissions, but no one country accounts for more than about 26 percent.”). 
emitting countries, as well as efforts to prevent increased emissions from developing countries.

Past successes with emissions trading support the incorporation of market-based measures into domestic and international climate policy negotiations. The Clean Air Act's Acid Rain Program, an early market-based approach capping of sulfur dioxide $\left(\mathrm{SO}_{2}\right)$ emissions from power plants, resulted in considerably lower than anticipated regulatory costs. ${ }^{8}$ The U.S. EPA subsequently implemented market-based systems to reduce nitrogen oxides emissions, regional haze in the Western U.S., and interstate impacts caused by sulfur dioxide, nitrogen oxides, and particulate matter emissions. ${ }^{9}$ The Acid Rain Trading Program also provided a model for the EU ETS and GHG markets in other countries. ${ }^{10}$

Market-based approaches are particularly well-suited for mitigating greenhouse gas emissions. The primary concern with GHG emissions is the global impact rather than local or regional impact, allowing flexibility with the location of emission reductions. Net reductions anywhere across the globe have the same relative benefit for atmospheric GHG concentrations. Furthermore, by defining a standardized tradeable instrument (e.g., an allowance representing the equivalent of a metric ton of $\mathrm{CO}_{2}$ ), emissions markets offer the potential to harmonize emissions reductions policies across multiple jurisdictions.

Market flexibility allows individual compliance entities to determine whether to reduce emissions at their facilities or search for lower-cost emissions reduction options that could occur elsewhere. In that context, buyers and sellers can experience "gains from trade." The seller of an emission allowance benefits by the revenue earned through the transaction. The buyer benefits by purchasing the allowance at a price that is lower than the cost of emissions abatement at the buyer's own facility. ${ }^{11}$ From an economic perspective, the most efficient emissions trading system has

8. 42 U.S.C. § 7651 (West, WestlawNext through P.L. 114-327); Curtis Carlson et al., Sulfur Dioxide Control by Electric Utilities: What Are the Gains from Trade?, 108 J. Pol. ECON. 1292, 1320 (2000); see also Robert N. Stavins, What Can We Learn from the Grand Policy Experiment? Lessons from $\mathrm{SO}_{2}$ Allowance Trading, 12 J. ECON. PERSPS. 69 (1998).

9. Cross-State Air Pollution Rule, 40 C.F.R. § 52, 78, 97 (2016) (The EPA also attempted to implement a cap-and-trade approach to reducing mercury emissions from the power sector, but the D.C. Circuit struck down the rule for reasons unrelated to emissions trading.); see $\mathrm{NO}_{x}$ Sip Call, 40 C.F.R. § 52 (1997); Regional Haze Regulations, 40 C.F.R. $\S 51$ (1999).

10. A. Denny Ellerman et al., Pricing Carbon: The European Union Emissions TRADING SCHEME 13-14 (2010).

11. See, e.g., Curtis Carlson et al., Sulfur Dioxide Control by Electric Utilities: What Are the Gains from Trade?, 108 J. POL. ECON. 1292 (2000) (describing the method of calculating gains from trade in emissions markets). 
one price that equates the marginal abatement cost across all emitting sources, favoring a single cap and a multi-jurisdiction, multi-sector strategy to reduce emissions. ${ }^{12}$

In the first decade of the 21st century, climate policy debates at both the international and domestic levels focused on uniform, top-down market strategies to reduce greenhouse gas emissions. The movement toward market-based climate policy in the U.S. started with the introduction of the McCain-Lieberman Climate Stewardship Act in $2003 .{ }^{13}$ The bill included a national cap on GHG emissions covering specified sectors of the economy and allowed these covered entities to trade emission allowances. Senate sponsors introduced progressively more detailed legislative proposals to create a national cap-and-trade system in 2005 and 2007. These early efforts focused attention on the complex policy tradeoffs associated with implementing a broad market system to limit GHG emissions and led to innovative regulatory design such as mechanisms that maintain the longterm emissions cap while relieving short-term price pressure in the event of extreme allowance price volatility. ${ }^{14}$

The high water mark for the U.S. carbon market debate occurred in 2009 when the House of Representatives passed the American Clean Energy and Security Act, introduced by Representatives Waxman and Markey (Waxman-Markey bill). The bill included complex provisions creating a GHG cap-and trade system, including an emissions cap that declined on a specified schedule between 2012 and 2050, specific rules for allowance allocation and auctioning, mechanisms to protect energy-intensive industries whose competitiveness could be jeopardized by higher energy prices resulting from the carbon price, offsets provisions, and a market oversight regime. ${ }^{15}$ The bill also included a federal renewable portfolio standard, energy efficiency incentives, and other policies to support energy innovation. ${ }^{16}$ After a contentious debate, the bill passed the House of Representatives by just three votes. The similar Boxer-Kerry-Lieberman bill stalled in the

12. For an overview of criticisms regarding market-based climate policy, see Nathaniel Keohane et al., Toward a Club of Carbon Markets, Climatic CHAngE 3-4 (Oct. 15, 2015), https://link.springer.com/article/10.1007/s10584-015-1506-z [https://perma.cc/MP64see also Alice Kaswan, Justice in a Warming World, ENVTL. F., July/Aug. 2009, at 48, 51, 58; Jonas J. Monast et al., On Morals, Markets, and Climate Change: Exploring Pope Francis' Challenge, Law \& Contemporary Problems (publication forthcoming).

13. Climate Stewardship Act of 2003, S. 139, 108th Cong. (2003).

14. Id.

15. American Clean Energy and Security Act, H.R. 2454, 111th Cong. (2009).

16. Id. 
U.S. Senate in $2010,{ }^{17}$ effectively halting congressional efforts to implement new federal legislation to mitigate climate change.

International efforts to address climate change began in earnest with the 1992 United Nations Conference on Environment and Development in Rio de Janeiro and the resulting United Nations Framework Convention on Climate Change (UNFCCC). ${ }^{18}$ The convention implemented the principle of "common but differentiated responsibilities," distinguishing between developed and developing countries. ${ }^{19}$ The agreement called upon developed countries to make binding commitments to reduce their respective GHG emissions. The Kyoto Protocol followed this bifurcated structure with emission reduction targets for developed countries, but no commitments for developing countries. ${ }^{20}$ The Kyoto Protocol implemented climate mitigation architecture for the initial period of 2008-12, with the U.N. serving as the central body for monitoring compliance. ${ }^{21}$

Although the Kyoto Protocol called upon countries to rely primarily on national measures to meet their respective emission reduction targets, the agreement established three flexible compliance mechanisms to facilitate market-based emissions abatement: international emissions trading, the Clean Development Mechanism (CDM), and Joint Implementation (JI). ${ }^{22}$ The latter two options fostered the first international offsets markets linked directly to compliance-based carbon markets. The CDM allowed developed countries to fund emission reduction activities in developing countries and receive certified emission reduction (CER) credits representing the equivalent

17. Carl Hulse \& David M. Herszenhorn, Democrats Call Off Climate Bill Effort, N.Y. Times, July 22, 2010.

18. Status of Ratification of the Convention, U.N. FRAMEWORK CONVENTION ON CLIMATE CHANGE, http://unfccc.int/essential_background/convention/status_of_ratification/items/ 2631.php [https://perma.cc/29ES-LXKL] (last visited Jan 2, 2017).

19. Kyoto Protocol to the United Nations Framework Convention on Climate Change, art. 10, Dec. 10, 1997, 37 I.L.M. 22.

20. Id. at Annex B (noting that the Kyoto Protocol lists developing countries with asterisks in Annex B. The Annex B countries largely mirror the list of UNFCCC Annex I member states). Compare UNFCCC, List of Annex I Parties to the Convention, with UNFCCC, Kyoto Protocol.

21. See Kyoto Protocol to the United Nations Framework Convention on Climate Change, supra note 19.

22. Id. at art. $6,12,17$. 
of one metric ton of $\mathrm{CO}_{2}\left(\mathrm{CO}_{2} \mathrm{e}\right)$ each, ${ }^{23}$ while $\mathrm{JI}$ enabled cooperation among developed countries, resulting in emission reduction units (ERUs). ${ }^{24}$

The Kyoto Protocol met with limited success. The U.S. was a signatory but declined to ratify the agreement, due in part to the failure to impose emission reduction targets on all nations. ${ }^{25}$ Some countries, such as Canada and Japan, signed on as parties to the agreement but did not meet their commitments. ${ }^{26}$ Canada subsequently withdrew from the Protocol altogether. ${ }^{27}$ Furthermore, the CDM has been the subject of intense criticism due to lack of effective oversight, difficulty verifying that the CDM projects resulted in additional emission reductions, and perverse incentives it creates for developing countries to increase emissions in order to attract emission reduction investments. ${ }^{28}$

The 2007 UNFCCC Conference of the Parties (COP) meeting in Bali sought to galvanize international efforts to complete a new legally binding international agreement. ${ }^{29}$ Negotiators agreed to the Bali Action Plan, a series of steps intended to foster a new legally-binding international agreement by the 2009 Copenhagen COP. The Action Plan focused on establishing stronger commitments for developed countries and creating firm commitments for middle-income countries. ${ }^{30}$

23. Conference of the Parties to the UNFCCC, Seventh Session, Marrakesh, Morocco, Oct. 29-Nov. 10, 2001, Modalities and Procedures for a Clean Development Mechanism, as Defined in Article 12 of the Kyoto Protocol, Annex, \ 1, U.N. Doc. FCCC/CP/2001/ 13/Add.2, Decision 17/CP.7, (Jan. 21, 2002); Joint Implementation (JI), U.N. FrAMEWORK CONVENTION ON CLIMATE CHANGE, http://unfccc.int/kyoto_protocol/mechanisms/joint_ implementation/items/1674.php [https://perma.cc/S8VS-F3MP] (last visited Mar. 1, 2017).

24. UNFCCC, Joint Implementation (2014), http://unfccc.int/kyoto_protocol/mechanisms/ joint_implementation/items/1674.php [https://perma.cc/J7M7-NH94].

25. See, e.g., Greg Kahn, The Fate of the Kyoto Protocol Under the Bush Administration, 21 BERKELEY J. INT’L L. 548, 550 (2003).

26. Isabeau Doucet, Canada, the Surprise 'Pariah' of the Kyoto Protocol, THE GuARDIAN, Nov. 26, 2012.

27. Canada Pulls Out of Kyoto Protocol, CBC News, Dec. 12, 2011; Andrew Light, Has Japan Killed the Kyoto Protocol?, CTR. FOR AM. Progress: ENERGY \& ENV'T (Dec. 8, 2010, 9:00 AM), https://www.americanprogress.org/issues/green/news/2010/12/08/ 8733/has-japan-killed-the-kyoto-protocol/ [https://perma.cc/HD4R-8AG3].

28. See, e.g., Michael Wara, Measuring the Clean Development Mechanism's Performance and Potential, 55 UCLA L. REV. 1759, 1783-85 (2008).

29. UNFCCC, Conference of the Parties, Thirteenth Session, Bali, Indon., Dec. 315, 2007, Decision 1/CP.13: Bali Action Plan, U.N. Doc. FCCC/CP/2007/6/ADD.1 (Mar. 14, 2008), http://unfccc.int/resource/docs/2007/cop13/eng/06a01.pdf\#page=3 [https://perma. cC/Z9EM-X9SQ].

30. Id. 
The Copenhagen COP failed in its effort to replace the Kyoto Protocol with a more comprehensive agreement. ${ }^{31} \mathrm{~A}$ number of factors contributed to the diplomatic failure, including: the different views of the relative roles of developed versus developing nations, the sheer number of nations negotiating with one another, and the difficulty simply agreeing on what global greenhouse gas concentration is necessary to avoid "dangerous" climate change. $^{32}$

While the Copenhagen COP did not achieve the grand international agreement envisioned in the Bali Action Plan, negotiators were able to salvage the UNFCCC process by reaching agreement on a limited set of steps. The Copenhagen Accord called upon individual countries to submit emission reduction targets to the UNFCCC, commit to the creation of an international Green Climate Fund to support mitigation and adaptation efforts in developing countries, and commit to continue negotiations through the UNFCCC process. ${ }^{33}$ The Copenhagen COP also resulted in progress on the Reducing Emissions from Deforestation and Forest Degradation in Developing Countries (REDD+) framework and agreement by the parties to the Kyoto Protocol to maintain a separate negotiating track aimed at extending the Protocol through $2020 .^{34}$

31. David G. Victor, Why the UN Can Never Stop Climate Change, THE GUARDIAN, Apr. 4, 2011 (noting how even before the Copenhagen COP, there were questions about the viability of a comprehensive, centralized global approach to climate change. As Professor Victor puts it: "The United Nations forum is the wrong place for serious diplomacy. One of the chief strengths of the UN system - that it involves every nation on the planet - is a huge liability for global warming. By working in large groups, UN talks are often held hostage to the whims of even small players-as happened in Copenhagen and Cancún when Sudan and Bolivia and a few other nations whose emissions of warming pollution are tiny. The UN system has also relied on legally binding agreements, which sound good in theory yet have proved difficult to tailor and adjust in light of the many different interests that must be reflected in any serious international pact to control emissions.”).

32. Keohane et al., supra note 12, at 14; Status of Ratification of the Convention, U.N. FRAMEWORK CONVENTION ON CLIMATE CHANGE, http://unfccc.int/essential_background/ convention/status_of_ratification/items/2631.php [https://perma.cc/MNK5-2H52] (last visited Mar. 1, 2017) (indicating there are 196 parties to the UNFCCC); see, e.g., Richard B. Stewart et al., A New Strategy for Global Climate Protection, 120 Climatic Change 1, 2 (2013).

33. See UNFCCC, Copenhagen Accord, U.N. Doc. FCCC/CP/2009/11/Add.1, Decision 2/CP.1 (Mar. 30, 2010).

34. See UNFCCC, Methodological Guidance for Activities Relating To Reducing Emissions from Deforestation and Forest Degradation and the Role of Conservation, Sustainable Management of Forests and Enhancement of Forest Carbon Stocks in Developing Countries, DeCISION 4/CP.15 (Dec. 19, 2009). 


\section{CARBON MARKET DEVELOPMENTS POST-2009}

The failure to implement a market-based approach through federal legislation in the U.S. and to reach a legally-binding international agreement at the Copenhagen COP dealt two potentially fatal blows to the prospect of market-based climate policy, and effective climate policy more generally. ${ }^{35}$ Multiple U.S. media outlets and think tanks declared the death of "capand-trade.” Political opposition to market-based climate policy persists today. ${ }^{36}$

Despite these high-profile setbacks, experimentation with carbon markets continued. Domestically, two state-based carbon markets launched in the United States between 2009 and 2012: the Regional Greenhouse Gas Initiative (RGGI), originally involving ten Northeast and Mid-Atlantic states, ${ }^{37}$ and the California Cap-and-Trade Program. ${ }^{38}$ The U.S. Environmental Protection Agency subsequently promulgated the Clean Power Plan, a rule limiting $\mathrm{CO}_{2}$ emission from existing fossil fuel-fired power plants. ${ }^{39}$

Globally, "[c]arbon markets are now the largest class of environmental or emissions trading markets ...., in terms of both market volume and

35. Ezra Klein, Cap-and-Trade Is Dead, WASH. Post, July 19, 2010, http://voices. washingtonpost.com/ezra-klein/2010/07/were_not_getting_a_price_on_ca.html [https://perma. cc/P7N8-7KMX]; Patrick J. Michaels, Cap-and-Trade Is Dead. Long Live Cap-and-Trade, TOWNHALL (Sept. 18, 2009), http://townhall.com/columnists/patrickjmichaels/2009/09/18/ cap-and-trade_is_dead_long_live_cap-and-trade/page/full [https://perma.cc/4XVV-EH2M]; Kimberley Strassel, Cap and Trade Is Dead, WALL ST. J., Nov. 26, 2009, http://www.wsj. com/articles/SB10001424052748703499404574558070997168360 [https://perma.cc/BQL65CBB]; see, e.g., Nate Silver, Cap-and-Trade is Dead; Long Live Cap-and-Trade, FIVE THIRTY EIGHT (July 28, 2010), http://fivethirtyeight.com/features/cap-and-trade-is/ [https:// perma.cc/TR6F-KMTK].

36. Bryan Walsh, Battle Brews Over EPA's Emissions Regulations, TIME, Jan. 30, 2011, http://content.time.com/time/health/article/0,8599,2040485,00.html [https://perma.cc/ S893-YNZW] (quoting then-EPA Assistant Administrator Gina McCarthy as stating that the forthcoming rules limiting $\mathrm{CO}_{2}$ emissions from existing power plants would be emissions standards rather than a "[carbon] cap program" (inserted language in original)).

37. Welcome, REGIONAL GREENHOUSE GAS INITIATIVE, www.rggi.org [https://perma. cc/T9GB-5MBL] (last visited Mar. 21, 2017); see discussion infra notes 157-59 (noting that New Jersey dropped out of RGGI in 2013).

38. Cap-and-Trade Program, CAL. AIR RESOURCES BOARD, http://www.arb.ca.gov/ cc/capandtrade/capandtrade.htm [https://perma.cc/F2ZD-HCTB] (last visited Mar. 14, 2017).

39. Clean Power Plan for Existing Plants, U.S. Envtl. Protection Agency, https://www.epa.gov/cleanpowerplan/clean-power-plan-existing-power-plants [https://perma. cc/TAM4-ESQD] (last visited Mar. 14, 2017). 
market value, by a wide margin." 40 The EU ETS is the largest and longest running carbon market. ${ }^{41}$ Norway and New Zealand have established carbon markets. ${ }^{42}$ South Korea launched a carbon market in 2015 and plans to pursue linkage with the EU ETS. ${ }^{43}$ China and Canada are implementing a national carbon market after experimentation at the provincial levels. ${ }^{44}$ China's new ETS will be the world's largest carbon market, with the cap potentially set at 4 billion tons-twice the size of the EU ETS and larger "than all existing carbon markets combined." ${ }^{45}$ In 2016, nations ratified the Paris Agreement, which calls for individual nations to identify and pursue their own GHG emission reduction strategies. ${ }^{46}$ Diplomats also concluded two major sector-specific agreements to aid global GHG mitigation efforts: an amendment to the Montreal Protocol phasing out the production and

40. Richard G. Newell, et al., Carbon Markets 15 Years after Kyoto: Lessons Learned, New Challenges, 27 J. ECON. PERS. 123, 124 (Winter 2013).

41. Climate Action: The EU Emissions Trading System (EU ETS), EUR. COMMISSION, https://ec.europa.eu/clima/policies/ets_en [https://perma.cc/6SAX-AUDE] (last updated Mar. 10, 2017).

42. Marion Afriat et al., New Zealand: An Emissions Trading Case Study, EnvTL. DEF. FUND, https://www.edf.org/sites/default/files/new-zealand-case-study-may2015.pdf [https://perma.cc/8JAQ-3JLY] (last updated May 2015); see Anthony Mansell \& Peter Sopher, Norway- The World's Carbon Markets: A Case Study Guide to Emissions Training, ENVTL. DEF. FunD, https://www.edf.org/sites/default/files/EDF_IETA_Norway_Case_Study May_2013. pdf [https://perma.cc/FC7P-U3TE] (last updated May 2013).

43. Marion Afriat et al., Republic of Korea: An Emissions Trading Case Study, INT'L EMISSIONS TRADING Ass'N, https://ieta.wildapricot.org/resources/Resources/Case_Studies_Worlds _Carbon_Markets/republicofkorea_case\%20study_june_2015.pdf [https://perma.cc/8B2QXXG4] (last updated June 2015).

44. See Canada makes strides towards national carbon price by 2018, INT'L CTR. FOR TRADE \& SUSTAINABLE DEV. (Dec. 15, 2016), http://www.ictsd.org/bridges-news/biores/ news/canada-makes-strides-towards-national-carbon-price-by-2018 [https://perma.cc/8D3XR4NK]; Karen Haugen-Kozyra, Alberta Climate Leadership: Building the Biological Bridge, INT'L EMISSIONS TRADING Ass'N, http://www.ieta.org/resources/Resources/GHG_Report/ 2016/Alberta\%20Climate\%20Leadership\%20-\%20KHaugen-Kozyra.pdf [https://perma.cc/ XBA7-87HY] (last visited Mar. 7, 2017); see also Afriat, supra note 42; Marion Afriat et al., Québec: An Emissions Trading Case Study, InT'L EMISSIONs Trading Ass'n, http:// www.ieta.org/resources/Resources/Case_Studies_Worlds_Carbon_Markets/quebec_case _study-may2015.pdf [https://perma.cc/M8SA-K9XX] (last updated May 2015); Kathy Chen \& Stian Reklev, China's National Carbon Market to Start in 2016 -Official, REUTERS, Aug. 31, 2015.

45. Jeff Schwartz, China's Emission Trading System: Implications for Carbon Markets and Trade, INT'L EMISSIONS TRADING Ass'N 7 (Mar. 2016), http://www.ieta.org/ resources/China/Chinas_National_ETS_Implications_for_Carbon_Markets_and_Trade_I CTSD_March2016_Jeff_Swartz.pdf [https://perma.cc/CT3N-X3XS].

46. U.N. Conferences of the Parties, Adoption of the Paris Agreement, U.N. Doc FCCC/CP/2015?L.9 (Dec. 12, 2015), http://unfccc.int/resource/docs/2015/cop21/eng/l09. pdf [https://perma.cc/UF7L-85G4]; Press Release, John Kerry, The Paris Agreement to Enter Into Force, U.S. Dep’t of State (Oct. 5, 2016) (on file with the author). 
use of hydroflurocarbons (HFCs) and a new United Nations agreement to cap global aviation GHG emissions at the 2020 level. $^{47}$

Most of these developments represent unilateral policy measures that include market-based strategies. If these subnational or national efforts are to lead to multijurisdictional cooperation, policymakers will face the same design challenges as those described supra for top-down markets. These policymakers will also face additional layers of complexity associated with aligning market design choices, monitoring market actors and governmental entities, verifying the emission reductions occur, enforcement if malfeasance affects other jurisdictions, market oversight, offset policies, and cost containment measures. Failure to adequately align these measures could undermine the integrity of the market, the environmental goals of the system, or both.

This Part compares three policy approaches for limiting GHG emissions implemented in the aftermath of the Waxman-Markey bill and the Copenhagen COP. At the subnational level, the California Cap-and-Trade Program establishes a multi-sector emissions cap that declines over time. The California system includes express provisions regarding market linkage and currently operates as a linked market with the Canadian province of Quebec. The EPA's promulgation of the Clean Power Plan lays the foundation for multistate emissions trading as a compliance strategy. It is up to each state to determine whether to allow covered entities to trade, what instruments may trade, and whether to restrict trading partners. At the international level, the UNFCCC process has shifted away from establishing member states' emission reduction obligations through a single comprehensive agreement in favor of individual commitments by member states. ${ }^{48}$ The following discussion provides an overview of each approach and highlights the policy choices that guide initial market design options.

47. Press Statement, John Kerry, An Ambitious HFC Amendment to the Montreal Protocol, U.S. Dep’t of State (Oct. 15, 2016); see also Joe Ryan, Airline Industry \$24 Billion Emissions Pact Gets UN Approval, BLOOMBERG (Oct. 6, 2016), https://www.bloomberg. com/news/articles/2016-10-06/airline-climate-deal-on-path-to-adoption-approved-bycommittee [https://perma.cc/NCM3-7TUN].

48. The California market was under development prior to the Waxman-Markey debate and the Copenhagen COP, but the market did not become operational until 2012. 


\section{A. The California Cap-and-Trade Program}

The RGGI market and the California Cap-and-Trade Program are prominent examples of subnational experimentation with carbon markets. ${ }^{49}$ Both efforts arose from state-level choices to limit $\mathrm{CO}_{2}$ emissions in the absence of a federal requirement, but the two market systems evolved along different trajectories. While the RGGI states worked together to design the market system and subsequently enacted state statutes to allow the simultaneous launch and coordinated operation of the regional market, California first implemented its law and subsequently sought linkage partners. The California system provides a particularly useful lens through which to consider how initial design choices affect long-term development of the market. Furthermore, the state could potentially serve as a linchpin for at least three domestic and international markets through a linked market with Quebec, acceptance of international offsets, and the Clean Power Plan.

\section{State Policy Goals and Design Choices}

California's carbon market originated with the California Global Warming Solutions Act of 2006, commonly referred to as "AB 32." ${ }^{\text {" T0 }}$ The 13-page statute requires, inter alia, that the state reduce its emissions to 1990 levels by 2020 and maintain and continue reductions beyond 2020. The law tasked the state's Air Resources Board with creating a scoping plan to "achiev[e] the maximum technologically feasible and cost-effective reductions in greenhouse gas emissions from sources or categories of sources of greenhouse gases by 2020" and allowed the Board to implement "market-based compliance mechanisms" to comply with the regulations promulgated under the law. ${ }^{51}$ California officials sought to use the AB 32 framework to create a model for addressing climate change for other states, and potentially the federal government, to follow. ${ }^{52}$

49. See RGGI, Inc., RegIONAL GREENHOUSE GAs Initiative, https://www.rggi.org/ rggi [https://perma.cc/X7LA-ZLLH] (last visited Mar. 7, 2017); see also Marion Afriat et al., California: An Emissions Trading Case Study, InT'L EMISsIONS TRADING Ass'N, http:// www.ieta.org/resources/Resources/Case_Studies_Worlds_Carbon_Markets/california_ca se_study-may2015.pdf [https://perma.cc/7NXF-LBU9] (last updated Apr. 2015).

50. Assemb. B. 32, Ch. 488 (Cal. 2006) [hereinafter AB 32]; see also CAL. HEALTH \& SAFETY CODE $§ 38550$ (West, WestlawNext through Ch. 3 of 2017 Reg. Sess.); Assembly Bill 32 Overview, CAL. Air ResOuRCES BOARD (Aug. 5, 2014), http://www.arb.ca.gov/cc/ ab32/ab32.htm [https://perma.cc/5VM6-92GE].

51. CAL. HeAlth \& SAFETy Code $\S \S 38550,38570$ (West, WestlawNext through Ch. 3 of 2017 Reg. Sess.).

52. Samantha Young, California adopts sweeping climate plan, SEATTLE Pi (Dec. 11, 2008), http://www.seattlepi.com/national/article/California-adopts-sweeping-climateplan-1294584.php [https://perma.cc/8ZFU-XJJD] (mentioning that Republican Governor 
The California Cap-and-Trade Program launched in 2012, initially covering electric utilities and large industrial facilities emitting more than 25,000 metric tons of $\mathrm{CO}_{2}$ annually. ${ }^{53}$ Beginning in 2015, distributers of transportation fuels and natural gas became subject to the emissions cap, covering major emitting sectors that account for 85 percent of the state's emissions. ${ }^{54}$ The emissions cap is slated to decline approximately three percent per year between 2015-2020. ${ }^{55}$

California relies on imported electricity to meet approximately onequarter of its demand, a major portion of which is supplied by coal-fired power plants. ${ }^{56}$ State officials addressed the prospect of emissions leakage by requiring the first in-state purchaser of imported electricity to submit allowances for the $\mathrm{CO}_{2}$ emissions associated with the generation. ${ }^{57}$ This policy approach avoids a Commerce Clause challenge while still imposing consistent requirements on all electricity providers, thereby removing the incentive to increase imports to avoid a carbon price. ${ }^{58}$

The California system includes a number of mechanisms intended to minimize compliance costs. First, the Air Resources Board points to the market-based system itself as a means of controlling costs. ${ }^{59}$ Second, covered entities may use offset credits to meet up to eight percent of their respective

Arnold Schwarzenegger said "he believes the regulations will spur the state's economy and serve as a model for the rest of the country.").

53. Overview of ARB Emissions Trading Program, CAL. AIR Resources BoARD 1 (Feb. 9, 2015), http://www.arb.ca.gov/cc/capandtrade/guidance/cap_trade_overview.pdf [https://perma.cc/VT6J-9NT3].

54. Id.

55. Id.

56. California Energy Almanac, CAL. ENERGy COMMISSION, http://www.energy.ca.gov/ almanac/ [https://perma.cc/RC2P-R29L] (last visited Dec. 30, 2016); Editors, California Must Import One-Quarter of Its Electricity, REALCLEAR ENERGY (Jan. 30, 2012), http://www.realclearenergy.org/charticles/2012/01/30/california_must_import_one-quarter_ of_its_electricity.html [https://perma.cc/4CH2-ZDU9].

57. See Allocating Emissions Allowances Under a California Cap-and-Trade Program: Recommendations to the California Air Resources Board and the California Environmental Protection Agency, ECON. \& AlloCATION ADVISORY COMMISSION (Mar. 2010), http://www.climatechange.ca.gov/eaac/documents/eaac_reports/2010-03-22_EAAC_ Allocation_Report_Final.pdf [https://perma.cc/4FG3-AQJM].

58. For a discussion of the dormant Commerce Clause issues related to the California market, see, e.g., James W. Coleman, Importing Energy, Exporting Regulation, 83 FORDHAM L. REv. 1357, 1369 (2014); Erwin Chemerinsky et al., California, Climate Change, and the Constitution, 37 ENVTL. L. REP. 10653 (2007).

59. AB 32, supra note 50, at Legislative Counsel's Digest; Overview of ARB Emissions Trading Program, CAL. AIR RESOURCES BOARD (Feb. 9, 2015), http://www.arb.ca.gov/cc/ capandtrade/guidance/cap_trade_overview.pdf [https://perma.cc/Y2JE-LWXT]. 
compliance obligations. ${ }^{60}$ As of 2016, the California market only accepts five categories of U.S.-based offsets: forest projects, livestock projects, ozone depleting substances, mine methane capture, and rice cultivation projects. ${ }^{61}$ California officials are evaluating additional offset categories, including international offsets. ${ }^{62}$ The state has entered into memoranda of understanding with the governments of Chiapas, Mexico and Acre, Brazil. ${ }^{63}$ These steps could lead to acceptance of credits generated by the REDD+ program developed through the UNFCCC process. ${ }^{64}$ Third, the market system seeks to minimize the impacts of yearly fluctuations in electricity demand and hydropower availability through multi-year compliance periods and by allowing market participants to bank allowances for use during a later compliance period. ${ }^{65}$

Fourth, the California market includes an allowance reserve pool to mitigate price spikes. ${ }^{66}$ Allowances in the reserve pool are offered at a predetermined price at quarterly auctions. ${ }^{67}$ Market participants may purchase allowances from the reserve pool at quarterly auctions, thereby adding to the total pool of allowances available in the marketplace. ${ }^{68}$ These cost containment provisions are coupled with an auction price floor to maintain a minimum price signal. Together, these provisions represent value choices

60. Compliance Offset Program, CAL. AIR RESOURCES BOARD, http://www.arb.ca.gov/ cc/capandtrade/offsets/offsets.htm [https://perma.cc/E7LN-6J6W] (last visited Mar. 14, 2017).

61. CAL. Code REgs. tit. 17, § 95854 (WestlawNext through 3/10/17 Register 2017, No. 10).

62. Cal. Air Resource Board Resolution 13-7: Amendments to California Cap-andTrade Program, CAL. AIR ResourCEs BoARD (Apr. 19, 2013), https://www.arb.ca.gov/cc/ capandtrade/linkage/resolution13-7.pdf [https://perma.cc/BHN2-QWFV] (noting that the California carbon market program "establishes a mechanism to include international offset programs from an entire sector within a region.”).

63. Memorandum of Understanding on Environmental Cooperation Between the State of Acre of the Federative Republic of Brazil, the State of Chiapas of the United Mexican States, and the State of California of the United States of America, CAL. AIR RESOURCES BOARD (2010), https://www.arb.ca.gov/cc/capandtrade/sectorbasedoffsets/ 2010\%20MOU\%20Acre-California-Chiapas.pdf [https://perma.cc/VJS6-EJ5Y] (noting a prospect of accepting REDD credits).

64. UNFCCC, Decision 9/CP.19, Work Programme on Results-Based Finance to Progress the Full Implementation of the Activities Referred to in Decision 1/CP.16, Paragraph 70 (Nov. 22, 2013), http://unfccc.int/resource/docs/2013/cop19/eng/10a01.pdf\# page $=24$ [https://perma.cc/S5TN-SVVU]

65. Overview of ARB Emissions Trading Program, CAL. AIR Resources BoARD (Feb. 9. 2015), http://www.arb.ca.gov/cc/capandtrade/guidance/cap_trade_overview.pdf [https://perma.cc/66GM-DP5P].

66. Id.

67. CAL. Code Regs. tit. 17, § 95911(d)(1) (WestlawNext through 3/10/17 Register 2017, No. 10).

68. Auction and Reserve Sale Information, CAL. AIR RESOURCES BOARD, http://www.arb.ca. gov/cc/capandtrade/auction/auction.htm [https://perma.cc/P75X-BZV2] (last visited Mar. 14, 2017). 
that the market price should be high enough to incentivize investments intended to reduce emissions, while also controlling for higher than anticipated allowance prices. ${ }^{69}$

Not content with relying solely on the market price to spur investments, California combines the market system with additional policies affecting the production and consumption of energy. For example, California has one of the most aggressive renewable portfolio standards (RPSs) in the country, requiring investor-owned utilities, electricity service providers, and community choice aggregators to procure 33 percent of their total electricity from qualifying renewable energy resources by $2020{ }^{70}$ In 2015 , California lawmakers adopted a new law setting the RPS requirement at 50 percent by $2030 .{ }^{71}$

The California Cap and Trade Program distributes allowances through a combination of free allocation, auctions, and the allowance reserve. Recipients of free allowances vary depending on the sector. Industrial facilities receive their share of allowances directly. ${ }^{72}$ Allowances for the electric power sector and natural gas fuels go to electric distribution utilities and natural gas distributors, respectively, and these entities must use the value of the allowances to achieve emission reductions and benefit ratepayers. ${ }^{73}$ Furthermore, the state sought to ensure transparency and avoid market manipulation through market oversight mechanisms governing the transfer of allowances. ${ }^{74}$

\section{Market Linkage}

The design of the California market system occurred in parallel with efforts to design a regional carbon market through the Western Climate Initiative (WCI). At its height, the WCI included seven U.S. states and

69. CAL. Code REgs. tit. 17, §§ 95911(b)(6)(A), 95913(d)(2) (WestlawNext through 3/10/17 Register 2017, No. 10).

70. RPS Program Overview, CAL. PUB. UTIL. COMMISsIOn, http://cpuc.ca.gov/ RPS Overview/ [https://perma.cc/MG9F-WPRG] (last visited Mar.14, 2017). For information about other states RPS requirements, see Database of State Incentives for Renewables \& Efficiency, N.C. ClEAN ENERGY TECH. CTR., http://www.dsireusa.org/ [https://perma.cc/ KP9R-PAJH] (last visited Mar.23, 2017).

71. SB350 Clean Energy and Reduction Act of 2015, Chapter 547, https://leginfo. legislature.ca.gov/faces/billNavClient.xhtml?bill_id=201520160SB350 [https://perma.cc/ 7U2E-J89B] (Approved by Governor Oct. 7, 2015, Filed with Secretary of State, Oct. 7, 2015).

72. Id.

73. Id.

74. Id. 
four Canadian provinces. ${ }^{75}$ Together, these subnational jurisdictions developed a coordinated set of design recommendations for a regional cap-and-trade program, including: the scope of the program, ${ }^{76}$ the emissions threshold for entities subject to the emissions cap, ${ }^{77}$ the regional emissions cap and how it would be apportioned among the WCI partner jurisdictions, ${ }^{78}$ provisions for program expansion, ${ }^{79}$ distribution of allowances, ${ }^{80}$ the use of offset credits, ${ }^{81}$ monitoring and reporting requirements, ${ }^{82}$ enforcement provisions, ${ }^{83}$ and linkage. ${ }^{84}$ The WCI market did not materialize, but the California system incorporates many aspects from the WCI process.

The California program expressly contemplates market linkage. California regulations require the governor to make the following findings before the state may link its carbon market with another jurisdiction:

(1) The jurisdiction with which the state agency proposes to link has adopted program requirements for greenhouse gas reductions, including, but not limited to, requirements for offsets that are equivalent to or stricter than those required by [California law].

(2) Under the proposed linkage, the State of California is able to enforce [its laws] against any entity subject to regulation under those statutes, and against any entity located within the linking jurisdiction to the maximum extent permitted under the United States and California Constitutions.

(3) The proposed linkage provides for enforcement of applicable laws by the state agency or by the linking jurisdiction of program requirements that are equivalent to or stricter than those required [by California law].

75. U.S. state partners included Arizona, California, Montana, New Mexico, Oregon, Utah, and Washington. Design Recommendations for the WCI Regional Cap-and-Trade Program, WCI Appendix A (Sept. 23, 2008), http://www.energy.ca.gov/2008publications/ WCI-1000-2008-025/WCI-1000-2008-025.PDF [https://perma.cc/SM82-QMCS] [hereinafter WCI Design Recommendations]. Canadian partners included British Columbia, Manitoba, Ontario, and Quebec. Id. The following Canadian provinces, U.S. States, and Mexican states participated in the WCI process as observers: Saskatchewan, Alaska, Colorado, Idaho, Kansas, Nevada, Wyoming, Baja California, Chihuahua, Coahuila, Nuevo Leon, Sonora, and Tamaulipas. Id. at i.

76. WCI Design Recommendations, supra note 75, at 1-3.

77. Id. at 3. The recommended emissions threshold was 25,000 tons of $\mathrm{CO}_{2}$ equivalent $\left(\mathrm{CO}_{2} \mathrm{e}\right)$ per year. $I d$.

78. Id. at 4-7. The WCI sought to achieve a $15 \%$ reduction in $\mathrm{CO}_{2} \mathrm{e}$ emissions below 2005 levels by 2020. Program Design, WCI, http://www.westernclimateinitiative.org/ designing-the-program [https://perma.cc/Z4F5-4J57] (last visited Mar. 23, 2017).

79. WCI Design Recommendations, supra note 75, at 3.

80. Id. at $7-10$.

81. Id. at 12 .

82. Id.

83. Id. at $12-13$.

84. Id. at $13-14$. 
(4) The proposed linkage and any related participation of the State of California in Western Climate Initiative, Incorporated, shall not impose any significant liability on the state or any state agency for any failure associated with the linkage. 85

On October 1, 2013, the governments of California and Quebec formally linked their respective carbon markets. ${ }^{86}$ In April 2015, the Ontario Premier announced that the province would join the linked carbon market, although California has not taken formal steps to facilitate the process as of October $2016 .{ }^{87}$ To date, no other WCI participants have announced plans to pursue linkage with California.

Allowing offset credits into the California market also creates the potential for indirect market linkage with other jurisdictions accepting the same credits. If multiple markets accept the same offset credits, the offset provider will sell credits in the market with the higher allowance prices. ${ }^{88}$

\section{B. U.S. Clean Air Act}

The U.S. Environmental Protection Agency's Clean Power Plan creates the potential for a national emissions trading system to emerge in the United States. In contrast to the explicit market design choices at the heart of the California Cap-and-Trade Program, however, prospects for carbon trading under the Clean Air Act depend on implementation choices by 47 states. ${ }^{89}$ This subpart discusses the Clean Power Plan as it exists at the time

85. CAL. Gov’T CODE $§ 12894$ (West, WestlawNext through Ch. 3 of 2017 Reg. Sess.).

86. Agreement Between the California Air Resources Board and The Gouvernment Du Québec, Concerning: The Harmonization and Integration of Cap-and-Trade Programs for Reducing Greenhouse Gas Emissions, CAL. AIR RESOURCES BOARD (Sept. 25-27, 2013), http://www.arb.ca.gov/cc/capandtrade/linkage/ca_quebec_linking_agreement_english.pdf [https://perma.cc/567H-47JW].

87. News Release: Cap and Trade System to Limit Greenhouse Gas Pollution in Ontario: Provincial System will Reward Innovative Companies and Create More Opportunities for Investment in Ontario, OfF. Premier ONT., CAN. (Apr. 13, 2015), https://news.ontario.ca/ opo/en/2015/04/cap-and-trade-system-to-limit-greenhouse-gas-pollution-in-ontario.html [https://perma.cc/7B4T-JRTK]; see also Allison Martell \& Mike De Souza, Ontario Confirms It Will Join Quebec, California in Carbon Market, REUTERS (Apr. 13, 2015), http://www.reuters.com/article/us-climatechange-canada-idUSKBN0N41X220150413 [https://perma.cc/LA5Y-B4NJ].

88. See, e.g., Daniel M. Bodansky et al., Faculty Research Working Paper Series, Facilitating Linkage of Heterogeneous Regional, National, and Sub-National Climate Policies Through a Future International Agreement, HARV. KENNEDY SCH. (Jan. 2015).

89. See Clean Power Plan-State Specific Fact Sheets, U.S. ENVTL. PROTECTION AGENCY, https://www.epa.gov/cleanpowerplantoolbox/clean-power-plan-state-specific-fact-sheets 
of publication. Although the Trump Administration has taken initial steps to overturn the rule, the rule development process and the market-based approaches included in the final version of the rule offer important lessons for future climate policy efforts. The subpart begins by summarizing the Clean Air Act provisions underlying the rule, and then explores the rule's emissions trading options and the tradeoffs that may impact the emergence and expansion of markets under this regulatory framework. ${ }^{90}$

\section{1. $\mathrm{CO}_{2}$ Performance Standards for the Electric Power Sector}

While the House of Representatives debated the Waxman-Markey bill in 2009, the EPA was in the early stages of regulating GHG emissions under the Clean Air Act. In 2007, the Supreme Court determined that the Clean Air Act's definition of "pollutant" applied to GHGs, thereby requiring the EPA to determine whether the gases endanger public health and welfare. ${ }^{91}$ The EPA made such a finding in 2009, which triggered implementation of a suite of new regulations to limit GHG emissions from motor vehicles and stationary sources. ${ }^{92}$

The EPA promulgated performance standards limiting $\mathrm{CO}_{2}$ emissions from the electric power sector pursuant to Clean Air Act Section 111. That section of the Act instructs the EPA to define categories of stationary sources emitting air pollutants that "cause, or contribute[] significantly to, air pollution which may reasonably be anticipated to endanger public health or welfare," then develop performance standards for new or modified sources emitting those pollutants. ${ }^{93}$ According to the EPA's interpretation, Section 111 also applies to existing stationary sources in the rare circumstance when (1) a pollutant is regulated under section 111, (2) the existing source falls within a source category also regulated under section 111, and (3) the air pollutant in question is neither regulated under the National Ambient Air

[https://perma.cc/N82X-Z56M] (last updated Sept. 16, 2016 at 6:00 PM EDT) (demonstrating that states that the Clean Power Plan does not apply to Alaska Hawaii or Vermont, as fact sheets are not available for those states).

90. On September 28, 2016, the D.C. Circuit held oral arguments in a case challenging numerous aspects on the Clean Power Plan. West Virginia v. E.P.A., No. 15-1363 (D.C. Cir. argued Sept. 28, 2016). Although the outcome of the litigation is unknown, the rule's trading provisions provide a useful lens through which to consider bottom-up market developments.

91. Massachusetts v. E.P.A., 549 U.S., 497, 528 (2007).

92. Endangerment and Cause or Contribute Findings Under Section 202(a) of the Clean Air Act, 74 Fed. Reg. 66,496 (proposed Dec. 15, 2009) (to be codified at 40 C.F.R. ch. 1). 327).

93. 42 U.S.C.A. §§ 7411(b)(1)(A), (b)(1)(B) (West, WestlawNext through P.L. 114- 
Quality Standards or Hazardous Air Pollutant programs. ${ }^{94}$ Carbon dioxide emissions from existing fossil fuel-fired power plants meet these criteria.

Flexible performance standards lie at the heart of Section 111, which the statute defines as

a standard for emissions of air pollutants which reflects the degree of emission limitation achievable through the application of the best system of emission reduction which (taking into account the cost of achieving such reduction and any non-air quality health and environmental impact and energy requirements) the Administrator determines has been adequately demonstrated. 95

Section 111(d) embraces the cooperative federalism structure that is common in environmental statutes. Under the law, the EPA develops guidance for the states, approves or denies the state plans, and may issue federal performance standards in the event a state plan is deemed insufficient. ${ }^{96}$ It is the states, however, that have the primary responsibility for developing the performance standards for existing sources through a process "similar to" those provided for developing state implementation plans for NAAQS standards.$^{97}$ Unlike the requirements for new and modified sources, Section 111(d) does not require a uniform national standard, allowing states to develop tailored plans for the existing sources within their borders. ${ }^{98}$

There is little regulatory precedent that applies Section 111(d) and no direct judicial precedent interpreting the section's broad statutory language. ${ }^{99}$ The EPA has previously interpreted the statute to allow emissions averaging or trading among covered sources rather than requiring action at each covered source; however, these rules cover a much smaller and less heterogeneous group of sources than the Clean Power Plan. ${ }^{100}$ Petitioners challenging the Clean Air Mercury Rule (CAMR), issued pursuant to Section 111(b) and Section 111(d), argued that the statute requires continuous emissions

94. Id. § (d)(1). Litigants are challenging the third criterion based on a discrepancy in unresolved versions of section 111(d) included in the 1990 Clean Air Act Amendments.

95. $\quad 42$ U.S.C.A. $\S 7411(\mathrm{a})(1)$.

96. Publication of guideline documents, emission guidelines, and final compliance times, 40 C.F.R. 60.22 (2017).

97. 42 U.S.C.A. § $7411(\mathrm{~d})(1)$.

98. Id. § (b), (d).

99. Jonas Monast et al., Regulating Greenhouse Gas Emissions from Existing Sources: Section 111(d) and State Equivalency, 42 ENVTL. L. REP. NEWS \& ANALYSIS 1026 (2012).

100. See Emission Guidelines for Municipal Waste Combustor Metals, Acid Gases, Organics, and Nitrogen Oxides, 40 C.F.R. § 60.33b(d) (2017). 
reductions at every source subject to the rule. ${ }^{101}$ The court overturned the rule for other reasons and did not address the range of options available to the EPA under Section 111(d). ${ }^{102}$

\section{Clean Power Plan Overview}

On August 3, 2015, the U.S. EPA finalized new source performance standards (NSPS) governing $\mathrm{CO}_{2}$ emissions from new and modified power plants that fall within two source categories: steam electricity generating units (i.e., coal-fired and oil-fired units) and electricity generation turbines (i.e., natural gas-fired turbines). The release of the NSPS triggered the Section 111(d) provisions, and the EPA simultaneously released the Clean Power Plan covering $\mathrm{CO}_{2}$ emissions from existing power plants. ${ }^{103}$

The final Clean Power Plan identified three categories of emissions reduction strategies, or "building blocks," that together form the best system of emissions reduction: (1) improving efficiency at existing fossil fuel-fired steam units (i.e., coal-fired and oil-fired power plants), (2) increasing use of existing natural gas combined cycle turbines, and (3) incremental growth of renewable energy generation. ${ }^{104}$ The rule applies these building blocks to the fleet of existing fossil fuel-fired power plants in each state, resulting in state-specific emission limits. ${ }^{105}$

States have broad discretion to determine how to meet their emissions targets, and the compliance strategies available to them extend beyond those included in the building blocks used to calculate state goals. ${ }^{106}$ As a threshold matter, states may choose between a rate-based target (pounds of $\mathrm{CO}_{2}$ per megawatt hour of generation) and a mass-based target (tons of $\mathrm{CO}_{2}$ ). The states may then assign the emission rate targets or tonnage limits to each affected unit, or may rely on a combination of state energy policies and actions taken by power plant operators to achieve the overall

101. Final Brief of Environmental Petitioners at 27, New Jersey v. EPA, 517 F.3d 574 (D.C. Cir. 2008) No. 05-1097, 2007 WL 2155491.

102. New Jersey v. E.P.A., 517 F.3d 574, 583-84 (D.C. Cir. 2008).

103. Carbon Pollution Emission Guidelines for Existing Stationary Sources: Electric Utility Generating Units, 80 Fed. Reg. 64662-01 (proposed Oct. 23, 2015) (to be codified at 40 C.F.R. pt. 60), 2015 WL 6384905 [hereinafter Final CPP Rule]. For an overview of Section 111(d), see Jeremy Tarr, The Clean Air Act and Power Sector Carbon Standards: Basics of Section 111(d), DuKE NichOlAs Inst. FOR ENVTL. POL'y SOLUTIONS (Mar. 13, 2013), https://nicholasinstitute.duke.edu/sites/default/files/publications/ni_pb_13-03.pdf [https://perma.cc/36NY-E56E].

104. Final CPP Rule, 80 Fed. Reg. at 64667.

105. Id.

106. See 42 U.S.C.A. § 7411(d) (stating that section 111(d) grants states the authority to "establish standards of performance" and "provide[] for the implementation and enforcement" of those standards). 
state emission goal. ${ }^{107}$ The EPA's final rule also identifies several options for states to allow covered entities to trade emission credits under a massbased or a rate-based approach, and streamlines implementation of "tradingready" state plans through two proposed model rules. ${ }^{108}$

\section{Market-Based Clean Power Plan Compliance Options}

The evolution of market-based options under the Clean Power Plan reflects the Obama Administration's cautious initial approach to carbon markets in the aftermath of the failed effort to move climate legislation through Congress. Early in the rule development process, the EPA sought to deflect claims that it was seeking to impose a national cap-and-trade system through the Clean Air Act-essentially accomplishing through regulation what supporters of climate legislation could not accomplish in Congress. ${ }^{109}$ Rather than streamlining the development of a market-based approach by offering states a model rule that they could voluntarily submit as their state plan - the approach used in CAMR ${ }^{110}$ — the Agency instead offered four regulatory pathways from which each state could choose. ${ }^{111}$ Two of those pathways allowed states to incorporate market-based compliance into their Clean Power Plan plans: a pathway allowing states to jointly develop a multistate trading system and a pathway whereby a state could submit an individual state plan that incorporated an intrastate

107. Final CPP Rule, 64 Fed. Reg. at 64664.

108. Id. at 64734 .

109. Obama Administration Pushing 'Backdoor' Cap-and-Trade Tax, NewsMax (Dec. 30, 2010), http://www.newsmax.com/InsideCover/obama-cap-and-trade/2010/12/30/id/ 381453/ [https://perma.cc/8AU2-G5VV]; see, e.g., Geoffrey Stiles, Does EPA's $\mathrm{CO}_{2}$ Rule Open A Back Door to Cap \& Trade?, ENERGY TRENDS INSIDER (June 12, 2014), http://www. energytrendsinsider.com/2014/06/12/does-epas-co2-rule-open-a-back-door-to-cap-trade/ [https://perma.cc/MLC8-2JTA].

110. New Jersey v. E.P.A., 517 F.3d 574 (D.C. Cir. 2008).

111. The pathways included an EGU-specific approach, a portfolio approach, a state commitment approach, and a multistate approach. Carbon Pollution Emission Guidelines for Existing Stationary Sources: Electric Utility Generating Units, 79 Fed. Reg. 34,83001, 34,900-02, 34,910-12 (proposed June 18, 2014) (to be codified at 40 C.F.R. pt. 60) [hereinafter Proposed Clean Power Plan]. For an overview of each state option included in the Proposed Clean Power Plan, see Lissa Lynch et al., Clean Power Plan Implementation: Overview of Potential Compliance Pathways, Geo. Climate CTR. 4 (Jan. 2015), http://www. georgetownclimate.org/sites/www.georgetownclimate.org/files/GCC_CompliancePathw aysOverview_January2015_0.pdf [https://perma.cc/Z7T6-UC7L]. 
market. ${ }^{112}$ RGGI and the California Cap-and-Trade Program could qualify under these respective options.

The proposed Clean Power Plan highlighted the tension between the economic benefits of a multistate market-based approach and the political and administrative hurdles to creating state-based emissions markets. Economic modeling of the proposed rule suggested that on average compliance costs would be lower under a multistate approach, whether it be rate-based or mass-based. ${ }^{113}$ Despite the potential to reduce overall compliance costs, developing state or regional markets presented political and administrative hurdles that raised questions about the viability of market approaches for many states. ${ }^{114}$ The notion of a cap-and-trade system to limit GHG emissions remains a politically controversial proposition. ${ }^{115}$ State officials, therefore, may face significant opposition from others within state government if they propose designing a market system to comply with the Clean Power Plan.

While the prospect of developing a market system for an individual state may have seemed politically infeasible, the additional requirement that states negotiate with one another in order to develop a multistate market made it even less likely that states would choose that option. Such a process would require the states to agree on a unified set of design features and could have exacerbated attention on the state's role in implementing a politically contentious carbon market. ${ }^{116}$ Furthermore, some states faced lower projected compliance costs than others, creating the concern that cooperation would raise energy prices in the lower cost states. Despite potential gains from trade bringing economic benefits to

112. See Lynch et al., supra note 111, at 4.

113. Martin T. Ross et al., Assessing Impacts of the Clean Power Plan on Southeast States (Duke Nicholas Inst. for Envtl. Pol’y Solutions, Working Paper NI WP 15-03, 2015), https://nicholasinstitute.duke.edu/sites/default/files/publications/ni_wp_15-03_full_pdf.pdf [https://perma.cc/U9U5-WAU3]; see also Jennifer Macedonia et al., Insights from Modeling the Proposed Clean Power Plan, BIPARTISAN POL’y CTR. 5 (Apr. 2015), http://bipartisan policy.org/wp-content/uploads/2015/04/BPC-Clean-Power-Plan-Slides.pdf [https://perma.cc/ CZ2D-PFYH] (“Adopting policy designs that allow access to emission reduction opportunities in other states tends to significantly lower the cost of compliance and reduce [power plant] retirements.”); Martin T. Ross et al., The Clean Power Plan: Implications of Three Compliance Decisions for U.S. States 1 (Duke Nicholas Inst. for Envtl. Pol'y Solutions, Working Paper NI WP 15-02, 2015), https://nicholasinstitute.duke.edu/sites/default/files/publications/ni_ wp_15-02_full_pdf.pdf [https://perma.cc/JLW6-Y89W] (“[A] mass-based approach, especially with multistate cooperation, offers large cost savings opportunities.”).

114. Jonas Monast et al., Enhancing Compliance Flexibility under the Clean Power Plan: A Common Elements Approach to Capturing Low-Cost Emissions Reductions, DuKE NiCHOLAS INST. FOR ENVTL. POL’y SOLUTIONS 2 (Mar. 2015), https://nicholasinstitute.duke.edu/ sites/default/files/publications/ni_pb_15-01.pdf [https://perma.cc/C53W-KFQ5].

115. Id. at 3 .

116. Id. 
the lower cost state, the prospect of potentially raising costs and the complexity associated with evaluating potential gains from trade, contributed to the political infeasibility of the multistate option provided for in the proposed rule. ${ }^{117}$

During the proposal phase, a handful of organizations released white papers demonstrating the potential for additional pathways that would allow multistate emissions markets to emerge without requiring state officials to affirmatively develop the markets or negotiate with their counterparts in other states. ${ }^{118}$ These strategies, referred to as "common elements," "trading-ready,"120 and “opt-in” compliance systems, ${ }^{121}$ highlighted the potential for states to streamline the requirements for trading by incorporating similar provisions in their respective plans. At minimum, states wishing to pursue this approach would need to allow the use of tradable instruments for compliance, adopt a common definition for the instruments (e.g., an allowance representing one ton of $\mathrm{CO}_{2}$ ), and include provisions for a tracking system to ensure that the instrument meets the state's criteria and protects

117. Carolyn Fischer et al., Using Emissions Trading to Regulate U.S. Greenhouse Gas Emissions; Part 1 of 2: Basic Policy Design and Implementation Issues, RESOURCES FOR FUTURE 4 (June 1998), http://www.rff.org/files/sharepoint/WorkImages/Download/ RFF-CCIB-10.pdf [https://perma.cc/6GK3-87FS] ("[G]ains from trade refers to the possibility of those with higher cost of abatement paying those with lower cost of abatement to undertake more emission control. Those with higher costs benefit by reducing their net cost of compliance - they pay others to undertake emission control, but they avoid even higher costs of controlling themselves. Those with lower costs benefit because they voluntarily enter into transactions that yield revenues at least as large as the extra control costs they assume. And society benefits by having a more cost-effective control program - fewer real resources devoted to the achievement of the environmental goal.”); see also Monast et al., supra note 114, at 3 ("[S]tates anticipating lower compliance costs than their neighbors may be reluctant to allow interstate trading out of concern for higher electricity rates for their citizens.”).

118. Kathryn Zyla et al., Working Paper: Supporting State Plan Compatibility and Interstate Compliance with the Clean Power Plan, GeO. Climate CTR. (July 2015), http://www.georgetownclimate.org/files/report/GCC_InterstateCompatibility_July2015_ 0-2.pdf [https://perma.cc/UVQ8-AAJ5]; see also Franz T. Litz \& Jennifer Macedonia, Choosing a Policy Pathway for State 111(d) Plans to Meet State Objectives (April 2015), http://www.betterenergy.org/sites/default/files/Policy\%20Pathways\%20Paper.pdf [https://perma. cc/45TM-6R59]; Monast et al., supra note 114.

119. Monast et al., supra note 114, at 2.

120. Franz T. Litz \& Jennifer Macedonia, Choosing a Policy Pathway for State 111(d) Plans to Meet State Objectives: Implementation Elements for a Trading-Ready Rate-Based Plan (May 2015), http://www.betterenergy.org/sites/default/files/Rate\%20Trading\%20 Ready_0.pdf [https://perma.cc/B9W3-ADX2].

121. Zyla et al., supra note 118 , at 2. 
against “double-counting” (e.g., previously submitted for compliance by any entity with a compliance obligation). ${ }^{122}$

The final Clean Power Plan rule embraces this approach to market-based compliance flexibility, expressly identifying "trading-ready" compliance pathways for either a mass-based or rate-based approach. ${ }^{123}$ The rule emphasizes that a mass-based approach provides a more straightforward option for the trading-ready system due to the simplicity of defining the tradable compliance instrument-a short ton of $\mathrm{CO}_{2} \cdot{ }^{124}$ States implementing a mass-based trading-ready option must either incorporate new fossil fuelfired power plants in the trading system or implement other mechanisms to mitigate the potential "leakage" of emissions from existing units covered by the Clean Power Plan to new units that are not. ${ }^{125}$ The numerous trading-ready pathways under the mass-based approach allow a common market to evolve even if states make different choices regarding allowance allocation, the treatment of new units, and other market design features.

The options for a rate-based trading-ready approach are more limited due to the complexity involved in defining tradable instruments based on heat rate efficiency. The only trading-ready rate-based pathway identified in the rule requires that states maintain the subcategorized rates for natural gas turbines and steam units (i.e., requiring natural gas units and steam units to meet the heat rate standard for their respective categories-771 and 1,305 pounds per megawatt hour for gas units and for steam units, respectively). States wishing to combine the two standards into a single "blended" state rate may only allow multistate trading with other states that also choose a blended rate approach, and then only if the blended rate states agreed to a single target that averaged each state's target. The EPA released two proposed model rules to streamline incorporation of the trading-ready options, one based on a mass-based trading-ready approach and the other based on a rate-based trading-ready approach. ${ }^{126}$

The trading-ready approach allows states to submit Clean Power Plan plans that preserve a power plant operator's ability to participate in an emissions market if doing so would be the most cost-effective compliance

122. If market-based compliance is permissible under the language of Clean Air Act section 111(d) - an issue that was briefed in the CAMR litigation but not addressed by the court - the statute itself would not restrict this option although it was unclear whether the proposal was permitted under the proposed rule. 42 U.S.C.A. § 7411.

123. Federal Plan Requirements for Greenhouse Gas Emissions from Electric Utility Generating Units Constructed on or Before January 8, 2014; Model Trading Rules; Amendments to Framework Regulations, 80 Fed. Reg. 64966, 65110 (proposed Oct. 23, 2015) (to be codified at C.F.R. pt. 60, 62, 78), 2015 WL 6384950.

124. Id. at 64970.

125. Id. at 64977-64978.

126. Id. at 64985 . 
option, but does not require the states to endorse the approach or engage in the resource-intensive process of designing the market or negotiating with other states. ${ }^{127}$

\section{Clean Power Plan Market Design Tradeoffs}

The trading-ready pathways included in the Clean Power Plan represent a hybrid approach to market development, with elements of both a topdown, rules-based approach, as well as a diffuse, bottom-up approach.128 States have broad discretion to choose among a range of compliance strategies, including whether or not to allow trading and, if so, what tradable instruments may satisfy covered entities' compliance obligations. Unlike the RGGI system, which is an example of a top-down approach with subnational jurisdictions working together to develop uniform policies necessary to establish a regional market, ${ }^{129}$ the EPA made key policy choices that requires action at the state level, yet constrains their choices. Most importantly, the EPA identifies the emission target for each state. ${ }^{130}$ As described above, the EPA's rule also constrains the range of options regarding tradable instruments.

The Clean Power Plan's hybrid approach to market development has its benefits. First, all existing electric generating units are subject to a carbon constraint. A mandatory emission limit ensures actions will occur that achieve the environmental policy goal. While intense political opposition remains, the Clean Power Plan spurred state regulators to focus attention on strategies to regulate carbon emissions, leading to a renewed interest in market-based approaches. Combining the top-down mandatory emission limit with a flexible regulatory program with a range of potential compliance

127. Id. at 64969.

128. Id. at 64975-64976.

129. To avoid Compact Clause challenges, each state participating in RGGI adopted its own legislation creating the program. Platform and User Information, REGIONAL GREENHOUSE GAS INITIATIVE, http://www.rggi.org/market/tracking/coats-platform [https://perma.cc/ EF7Z-LWLQ] (last visited Mar. 24, 2017). Each state's legislation was based on model legislation developed in conjunction with other RGGI states, and included consistent rules necessary for the regional market to operate effectively, including the emissions cap, trading provisions, use of offsets, and allowance distribution. Id.

130. Carbon Pollution Emission Guidelines for Existing Stationary Sources: Electric Utility Generating Units, 80 Fed. Reg. 64662, 64961 (Oct. 23, 2015) (to be codified at 40 C.F.R. pt. 60), 2015 WL 6384905. 
pathways allows individual jurisdictions - here state governments- to evaluate which strategies are most likely to achieve state policy goals. ${ }^{131}$

This decentralized approach to policy implementation may alleviate some of the political hurdles to market-based climate policy. The promulgation of the rule shifted the policy debate from whether to limit emissions, to how. By granting states the option to incorporate market-based options in their state plans, it allows an assessment of the value of markets in this context. The trading-ready approach could also have the long-term benefit of facilitating a trading infrastructure that can incorporate additional sectors and expand into a unified national system.

The trading-ready concept facilitates state choices and may mitigate some degree of political controversy regarding market-based compliance because the EPA is allowing, rather than imposing, market-based compliance options. However, allowing the states to decide whether to allow emissions trading could result in a more expensive and administratively complex approach to national emission reductions than a single, coordinated market strategy.

Despite the potential downsides to the bottom-up decision-making process, created by allowing states to choose among numerous trading ready pathways, the EPA's focus on the minimal criteria necessary to allow market-based compliance offers a useful model for national and international efforts to foster broad cooperation on emission reduction goals. As discussed in Part $\mathrm{IV}$, the trading ready approach may facilitate market linkage over time by streamlining key market design choices.

\section{UNFCCC Focus on Unilateral Commitments}

The UNFCCC negotiations continued to focus on a post-2020 agreement in the aftermath of the Copenhagen COP, but sought alternatives to the uniform, top-down approach. In 2011, the Durban COP produced a "platform for enhanced action" that established a "blueprint for a fresh universal, legal agreement to deal with climate change beyond 2020, where all will play their part to the best of their ability."132 The process leading up to the Paris COP settled on a decentralized, bottom-up process whereby each member country identified its individual emission reduction

131. Common state energy goals include maintaining affordable energy prices, but may also include efforts to promote specific energy options, or steer benefits to certain industries or consumers through allowance allocation strategies or auction proceeds.

132. Framework Convention on Climate Change dec. 1/CP.17, Mar. 15, 2012, U.N. FCCC/CP/2011/9/Add. 1 [hereinafter Durban Platform]; Towards full Implementation of the UN Climate Change Convention, U.N. FRAMEWORK CONVENTION ON CLIMATE CHANGE, http://unfccc.int/key_steps/durban_outcomes/items/6825.php [https://perma.cc/ Q7EZ-6V4N] (last visited Oct. 25, 2015). 
strategies through Intended Nationally Determined Contributions (INDCs) submitted to the UNFCCC. ${ }^{133}$ In addition to the emission reduction targets, the INDCs also included the means to implement and enforce the policies, as well as measures covering adaptation, finance, and funding to address climate change-related damages in developing countries. ${ }^{134}$

The UNFCCC members agreed to a long-term goal of stabilizing global emissions to limit temperature rise to no more than $2^{\circ}$ Celsius above preindustrial levels and committed to "pursu[e] efforts to limit the temperature increase to $1.5^{\circ}$ Celsius." ${ }^{\text {"35 }}$ The Paris Agreement calls for emissions neutrality by the end of the 21st Century, with a "balance between anthropogenic emissions and removals by sinks of greenhouse gases." ${ }^{\text {"36 }}$ The agreement codified the Nationally Determined Contributions (NDCs) approach, requiring the parties to update their NDCs every five years. ${ }^{137}$

Similar to the U.S. EPA's actions under the Clean Air Act, the postCopenhagen UNFCCC process relies on individual countries to determine whether and how to pursue multilateral cooperation. Unlike the U.S. regulatory approach, however, the Paris Agreement lacks an overarching policy identifying the emissions limits for member nations and uniform oversight and enforcement provisions. ${ }^{138}$

133. Framework Convention on Climate Change dec. 1/CP.19 (Jan. 31, 2014), U.N. FCCC/CP/2013/10/Add. 1, http://unfccc.int/focus/indc_portal/items/8766.php [https://perma.cc/ D8Q2-HR2A].

134. Durban Platform, supra note 132.

135. Paris Agreement art. 2.1(a), 2015, U.N. FCCC/CP/2015/10/Add.1, (Analysis of the INDC submissions demonstrate that additional measures will be necessary to achieve the $1.5-2^{\circ} \mathrm{C}$ goal.); see, e.g., John Reilly et al., Energy \& Climate Outlook Perspectives from 2015, MIT Joint PROGRAm ON Sci. \& Pol’y Global Change 2 (2015), https:// globalchange.mit.edu/sites/default/files/newsletters/files/2015\%20Energy\%20\%26\%20C limate\%20Outlook.pdf [https://perma.cc/2N7B-F574] ("Under the proposed cuts, the emissions path far exceeds levels consistent with the $2^{\circ} \mathrm{C}$ goal often used as a target in climate negotiations as a level necessary to prevent dangerous climate change.”); The Emissions Gap Report 2015: A UNEP Synthesis Report, U.N. ENV’T PROGRAMME (Nov. 2015), https://uneplive.unep.org/media/docs/theme/13/EGR_2015_301115_lores.pdf [https:// perma.cc/X9NT-VV74].

136. Paris Agreement, supra note 135, at art. 4.1.

137. Id. at art. 4.2, 4.9. Parties agreed to "prepare, communicate and maintain successive nationally determined contributions that it intends to achieve. Parties shall pursue domestic mitigation measures, with the aim of achieving the objectives of such contributions." Id. at art. 4.2.

138. See, e.g., Joseph Aldy, The Role of Domestic Policy Surveillance in the Multilateral Climate Transparency Regime, in The PARIS AgREEMENT AND BEYOND: INT'L CLIMATE CHANGE POL’Y POST-2020 43-46 (2016) (discussing the importance of domestic transparency 
The Paris Agreement offers two options for multilateral market-based mitigation strategies: The first allows parties to voluntarily engage in "cooperative approaches that involve the use of internationally transferred mitigation outcomes towards [NDCs], to promote sustainable development and to ensure environmental integrity and transparency, including in governance, and shall apply robust accounting to ensure, inter alia, the avoidance of double counting."139 This provision could include numerous options for bilateral or multilateral emission trading programs. ${ }^{140}$

The second option establishes an emission mitigation and sustainable development mechanism that does not depend upon emissions trading systems. The Agreement requires this mechanism to satisfy four criteria:

(a) ... promote the mitigation of greenhouse gas emissions while fostering sustainable development; (b) . . . incentivize and facilitate participation in the mitigation of greenhouse gas emissions by public and private entities authorized by a Party; (c) ... contribute to the reduction of emission levels in the host Party, which will benefit from mitigation activities resulting in emission reductions that can also be used by another Party to fulfil its nationally determined contribution; and (d) . . . deliver an overall mitigation in global emissions. ${ }^{141}$

This option is an expansion of the Kyoto Protocol's Clean Development Mechanism, which allows emission reduction projects in developing countries to generate credits that developed countries could apply towards their emission reduction targets. ${ }^{142}$ Parties to the Paris Agreement must continue to develop details regarding the mechanism, including what actions qualify for credit, how parties may transfer and account for the credits, and the relationship between the Paris Agreement's two market-based mitigation options. ${ }^{143}$ The emission reduction and sustainable development mechanism has the potential to complicate the international transfer of credits, and

and ex post review strategies to monitor countries' progress toward meeting their respective NDCs).

139. Paris Agreement, supra note 135, at art. 6.2.

140. A Vision for the Market Provisions of the Paris Agreement, InT'L EMISSIONS TrADING Ass'N 7-8 (May 2016), http://www.ieta.org/resources/Resources/Position_Papers/ 2016/IETA_Article_6_Implementation_Paper_May2016.pdf [https://perma.cc/28RL-Q7SQ]. 141. Paris Agreement, supra note 135, at art. 6.4.

142. Andrei Marcu, Carbon Market Provisions in the Paris Agreement (Article 6), CTR. EUR. POL'y STUD. 13 (Jan. 2006), https://www.ceps.eu/system/files/SR\%20No\%20128\%20 ACM\%20Post\%20COP21\%20Analysis\%20of\%20Article\%206.pdf [https://perma.cc/WX4SRPSC]; INT'L EMISSIONS TRADING Ass'N, supra note 140, at 8.

143. Thomas L. Brewer et al., Carbon Market Clubs and the New Paris Regime: Paper for the World Bank Group's Networked Carbon Markets Initiative, WorLD BANK 25-26 (2016), http://pubdocs.worldbank.org/en/323531476453676433/1700505-CarbonMarket-Clubs-Web.pdf [https://perma.cc/3HAM-9W7B]; Marcu, supra note 142, at 13. For information regarding the Clean Development Mechanism, see Clean Development Mechanism, U.N. FRAMEWORK CONVENTION CLIMATE CHANGE https://cdm.unfccc.int/ [https://perma.cc/G3GQ-94UM] (last visited Nov. 2, 2016). 
new accounting measures will be necessary to determine how the credits generated, pursuant to this mechanism, relate to the countries' NDCs.

\section{MOVING From Unilateral TO MULTILATERAL MARKET-BASED MEASURES}

The bottom-up emission reduction approaches described in Part IV represent incremental progress toward the goal of reducing global GHG emissions. The Clean Power Plan and the UNFCCC's focus on NDCs are modest in terms of their scope and emission reduction goals. The Clean Power Plan focuses on a single sector of the U.S. economy, seeking to achieve a 32\% reduction in electric power sector emissions by $2030 .{ }^{144}$ Many states are already on track to meet their emission targets with little or no additional action. ${ }^{145}$ Analysis of the INDC submissions demonstrate that the cumulative emission reductions fall well short of the Copenhagen COP goal of a stabilized $2^{\circ}$ Celsius increase, with some countries committing to emission reductions and others pledging to reduce carbon intensity rather than overall emissions. ${ }^{146}$ California's approach is more ambitious in terms of emission reduction mandates, but the state may not regulate activities beyond its borders. ${ }^{147}$

Despite their limitations, each of these steps has resulted in important policy experimentation and provided a foundation upon which more comprehensive emission reduction efforts may emerge. The long-term success of these efforts, therefore, depends less on near-term emission reductions and more on how the initial design choices affect future emission reduction options.

144. By The Numbers: Cutting Carbon Pollution from Power Plants, U.S. ENVTL. PROTECTION AGENCY, https://www.epa.gov/sites/production/files/2014-06/documents/ 20140602fs-important-numbers-clean-power-plan.pdf [https://perma.cc/9D8K-Z6UL] (last visited Mar. 14, 2017).

145. Jeremy Richardson et al., States of Progress: Existing Commitments to Clean Energy Put Most States in Strong Position to Meet the EPA's Final Clean Power Plan, Union Concerned Scientists (Aug. 13, 2015), http://www.ucsusa.org/global-warming/ reduce-emissions/clean-power-plan-states-of-progress\#.Vi11NKLnciE [https://perma.cc/ Q8KL-BZ9T]; see also Clean Power Plan Final Rule - Regulatory Impact Analysis, U.S. ENVTL. PROTECTION AGENCY, http://www2.epa.gov/cleanpowerplan/clean-power-plan-finalrule-regulatory-impact-analysis [https://perma.cc/Z5RT-S3YF] (last updated Oct. 22, 2015).

146. INDCs as Communicated by Parties, U.N. FramewOrK CONVENTION CLIMATE CHANGE, http://www4.unfccc.int/submissions/indc/Submission\%20Pages/submissions. aspx [https://perma.cc/U4RD-947E] (last visited Mar. 24, 2017).

147. Pike v. Bruce Church, Inc., 397 U.S. 137, 142 (1970). 
The next Part outlines three approaches to move from unilateral marketbased climate policy at the subnational or national levels to a broader, multilateral approach: market linkage, club architecture, and networked heterogeneous markets.

\section{A. Bilateral or Multilateral Market Linkage}

Numerous commentators point to market linkage as a strategy to move from individual commitments to a multilateral approach without formal international treaties. ${ }^{148}$ Linkage can take different forms. Two-way linkage involves two or more jurisdictions accepting emission allowances from one another. ${ }^{149}$ One-way linkage involves one jurisdiction accepting allowances from another, but not vice versa. ${ }^{150}$ One-way linkage can occur when a jurisdiction makes a unilateral decision to accept allowances from another jurisdiction or a unilateral decision to allow allowances to be sold in another jurisdiction. ${ }^{151}$ Indirect linkage involves systems that link with one system that then links with another. ${ }^{152}$ If State A links with State B, and State B

148. Rob Dellink et al., Towards Global Carbon Pricing: Direct and Indirect Linking of Carbon Markets, OECD J.: ECON. STUD. 209 (2014); Jane Ellis \& Dennis Tirpak, Linking GHG Emission Trading Schemes and Markets, ORG. FOR ECON. CoOPERATION \& DEV. (Oct. 2006), https://www.oecd.org/env/cc/37672298.pdf [https://perma. cc/DA9Z-88Y8]; Jessica F. Green et al., A Balance of Bottom-Up and Top-Down in Linking Climate Policies, 4 NAT'L Climate Change 1064-656 (2014); Sonja Hawkins \& Ingrid Jegou, Linking Emissions Trading Schemes: Considerations and Recommendations for a Joint EU-Korean Carbon Market, InT'L CTR. FOR TRADE \& SUSTAINABLE DEV. (Mar. 2014), http://www.ictsd.org/downloads/2014/03/linking-emissions-trading-schemes-considerationsand-recommendations-for-a-joint-eu-korean-carbon-market.pdf [https://perma.cc/U8HXEE3U]; Judson Jaffe et al., Linking Tradable Permit Systems: A Key Element of Emerging International Climate Policy Architecture, 36 Ecology L. Q. 789 (2009); Andrew J. O’Connell, A Critical Analysis of Allowance Allocation in Cap-and-Trade and Its Effect on Linked Carbon Markets, 44 TEX. ENVTL. L. J. 339, 366-72 (2014); Matthew Ranson \& Robert N. Stavins, Linkage of Greenhouse Gas Emissions Trading Systems: Learning from Experience (Harvard Kennedy Sch. Faculty Research Working Paper Series, 13-046, 2013); Matthew Ranson \& Robert N. Stavins, Post-Durban Climate Policy Architecture Based On Linkage Of Cap-And-Trade Systems, 13 CHI. J. INT'L L. 403 (2013); Peter Zaman \& Adam Hedley, The Regulatory Framework to Support Carbon Market Linkage - A Concept Paper, ReEDSmith (Apr. 26, 2016), http://pubdocs.worldbank.org/en/ 680061461687518813/The-Regulatory-Framework-to-support-the-NCM-Linking-Model.pdf [https://perma.cc/88MC-3Z9R]; see, e.g., The Paris Agreement and Beyond, supra note 138 , at 53-68.

149. Green et al., supra note 148, at 1064-66.

150. Id.

151. Newell et al., supra note 40, at 139-40.

152. Green et al., supra note 148, at 1064-65. 
links with State C, then State A and State C are indirectly linked. ${ }^{153}$ The allowance prices will equalize across all three jurisdictions. ${ }^{154}$

Expanding an existing market through linkage may not be a seamless process, as it may require policy adjustments on the part of the linking jurisdictions. These adjustments, in turn, may create barriers that slow or stall the linking process. A growing body of scholarship points to a club approach to foster multilateral cooperation on climate change mitigation and adaptation, including the development of carbon markets. A club framework may create an effective platform for market development, but still may face path dependency barriers if club members enter with established emissions trading markets. Existing linked carbon markets avoided these challenges by coordinating with prospective partners during the initial market design phase. Jurisdictions developing unilateral markets may also streamline future linkage by aligning policy choices with those of dominant existing carbon markets, such as the EU, ETS, or California Cap-andTrade Program. They may alternatively follow the Clean Power Plan's trading-ready model by identifying the minimal set of criteria necessary to facilitate future linkage.

Under a bottom-up linkage approach, choices by a diffuse collection of national and subnational actors affect whether and how markets evolve. Differences may emerge regarding the stringency of the emissions limit, which entities may trade, what instruments may satisfy compliance obligations (e.g., whether carbon offsets are allowed and, if so, whether there are differences in protocols or liability), how allowances make their way into the market (e.g., auction, free allocation, or a combination), and the incorporation of cost containment provisions.

The two subnational carbon markets currently operating in the U.S. differ in some key aspects, making them incompatible without alterations. The RGGI market applies to the electricity sector only, emissions are measured in short tons, and carbon offsets are limited by geography and the role they play in the market. ${ }^{155}$ In contrast, California's market covers multiple sectors, emissions are measured in metric tons, and the state establishes specific criteria for domestic and international carbon offset credits that may count as compliance. ${ }^{156}$

153. Id.

154. Id.

155. Welcome, REgiOnAL GREENHOUSE GAS InITIATIVE, www.rggi.org [https://perma. cc/Z8NE-B3TM] (last visited Jan. 6, 2017).

156. See supra notes 50-88. 
Policy instability introduces a degree of market uncertainty for emission markets created by bottom-up linkage. Compliance-based emissions markets exist due to policy choices, and those choices may be vulnerable to shifts in political leadership. Officials in states participating in RGGI grappled with this issue in 2012 when New Jersey Governor Chris Christie announced that his state would no longer participate in the RGGI market. ${ }^{157}$ The governor pursued the market exit despite the fact that the RGGI auction had generated \$188 million for the state and the move faced opposition in the state's legislature. ${ }^{158}$ The unilateral move required the remaining state participants to adjust the regional emissions cap and retire the 21 million allowances associated with New Jersey's share of the program. ${ }^{159}$

Australia offers another cautionary tale for linked markets. Australia's government ratified the Kyoto Protocol in 2007 and subsequently committed to reduce its emissions by 5\% below 2000 levels by 2020 under the Copenhagen Accord. ${ }^{160}$ The country also agreed to "reduce its greenhouse gas emissions by $25 \%$ on 2000 levels by 2020 if the world agrees to an ambitious global deal capable of stabilizing levels of greenhouse gases in the atmosphere at $450 \mathrm{ppm} \mathrm{CO}$-eq or lower," and "by up to $15 \%$ by 2020 if there is a global agreement which falls short of securing atmospheric stabilization at 450 ppm CO2-eq and under which major developing economies commit to substantially restrain emissions and advanced economies take on commitments comparable to Australia's."161

The Australian Parliament implemented a suite of laws to meet its Copenhagen commitments, including the Carbon Pricing Mechanism that started as a carbon tax and was to transition to an emissions trading system that linked with the EU ETS by 2015. ${ }^{162}$ After the 2013 Parliamentary elections resulted in a change in government, Prime Minister Abbott announced that Australia would shift its climate policy approach and abandon the

157. Governor Christie claimed that the market was a failure due to consistently low allowance prices. Justin Doom before New Jersey Exits RGGI, BLOOMBERG Bus. (Dec. 9, 2011), http://www.bloomberg.com/news/articles/2011-12-09/carbon-permits-sell-for-minimumbefore-new-jersey-exits-rggi [https://perma.cc/HD7 W- SRM4].

158. Id.; Maria Gallucci, NJ Legislators Working to Block Christie’s Carbon Market Exit, REUTERS (June 24, 2011), http://www.reuters.com/article/2011/06/24/idUS720020 50520110624 [https://perma.cc/26PJ-B2LN].

159. Doom, supra note 157.

160. Appendix I - Quantified economy-wide emissions targets for 2020, U.N. FRAMEWORK CONVENTION ON CLIMATE CHANGE, http://unfccc.int/meetings/copenhagen_dec_2009/items/5264. php [https://perma.cc/GM6W-N79S] (last visited Jan. 6, 2017).

161. Id.

162. Clean Energy Act, 2011, No. 131 (Austl.). For a summary of Australia's actions to address greenhouse gas emissions, see Marion Afriat et al., Australia: An Emissions Trading Case Study, INT'L EMISSIONS TRADING Ass'N, https://ieta.wildapricot.org/resources/Resources/ Case_Studies_Worlds_Carbon_Markets/australia_case_study_may2015.pdf [https://perma. cc/5REG-AAHL] (last updated May 2015). 
ETS. ${ }^{163}$ The transition occurred before the linkage with the EU ETS could take place, but emphasizes the uncertainties inherent in a decentralized, linked market system.

Jurisdictions implementing their own GHG emission reduction strategies may be vulnerable to forum shopping, as market actors with geographic flexibility may locate in jurisdictions with less stringent policies. ${ }^{164}$ Furthermore, a linked market approach may create an incentive for some jurisdictions to implement a less stringent emissions cap to reduce domestic allowance prices, or to bolster the domestic economy by attracting investment in the lower cost allowances. ${ }^{165}$

Beyond these overarching concerns that could fundamentally affect market function, the policy design process inherent in carbon market implementation may foster political and financial path dependency. To the extent a jurisdiction's initial market design choices reflect political compromises with key constituencies, there may be little flexibility to adjust those choices to facilitate market linkage. Similarly, initial decisions regarding emissions stringency and which instruments may trade in the market impact investments. Future alterations to these market elements may undermine the value of allowances purchased early for use at a later date. Moreover, investments made based on a less stringent emissions limit may result in stranded assets if a subsequently tighter cap makes the asset uneconomic to operate. ${ }^{166}$

Investments in offset projects may prove particularly vulnerable to path dependency concerns. These projects may require a multiple year leadtime before offset credits are available. A change in offset protocols before project maturity may undermine the project. As offset projects may represent both the potential to lower market costs by increasing the supply of compliance instruments as well as a political compromise to provide revenue opportunities for sectors such as forestry and agriculture, entrenched interests may quickly develop that would oppose linkage with other jurisdictions if that linkage affected offset supply in the market or individual offset projects.

163. Afriat et al., supra note 162, at 3.

164. Robert O. Keohane \& David G. Victor, The Regime Complex for Climate Change: Discussion Paper 2010-33, HARV. KENNEDY SCH. 17 (Jan. 2010), http://belfercenter.ksg.harvard.edu/ files/Keohane_Victor_Final_2.pdf [https://perma.cc/7YDY-XKK2].

165. Green et al., supra note 148, at 1066.

166. Barnett et al., Stranded Clean Air Costs: How Big?, 15 EleCTRICITY J., 64, 6468 (July 2002), http://www.auburn.edu/ thomph1/cleanair.pdf [https://perma.cc/2K5RFRA3]. 
California's experience with offsets liability offers a current example of a policy design choice that may affect future linkage options. ${ }^{167}$ The state's market regulations place liability for the offset credit on the purchaser of the offset. If the Air Resources Board determines that the credit is not valid due to a failure to meet all of the state's criteria, the purchaser may lose all value and have to look for additional compliance credits. ${ }^{168}$

California officials determined that perfect alignment with its offset liability requirements was not necessary for market linkage. Quebec created a buffer pool to serve as a backstop in the event an offsets project does not perform as projected rather than imposing liability on the holder of the offset credit. ${ }^{169}$ In the end, these strategies were compatible. Each prevented underperforming offset projects from undermining the emissions cap. In contrast, jurisdictions without an effective mechanism to protect against problems with offsets credits would likely fail California's requirement that linked jurisdictions include requirements for offsets that are at least as stringent as the state's own provisions. ${ }^{170}$

167. For example, if a forest offsets project sells credits into a market but later burns, the project may fail to sequester carbon. Charles Schmidt, Carbon Offsets: Growing Pains in a Growing Market, 117 ENVTL. HEALTH PERSPS. 62, 62 (Feb. 2009), https://ehp.niehs.nih.gov/ wp-content/uploads/117/2/ehp.117-a62.pdf [https://perma.cc/CC7U-DBE3].

168. A recent example highlights the liability process. In September 2015, the Air Resources Board launched an investigation to determine whether a dairy farm selling offset credits for livestock methane destruction was in compliance with the permitting rules of Indiana the state where it is based, as required by the California's Cap-and-Trade Regulation. CAL. CodE REgs. tit. 17, § 95985(c)(2) (WestlawNext through 3/10/17 Register 2017, No. 10); Amendments to California's Cap-and-Trade Program: Final Statement of Reasons, CAL. AIR ResOuRCES BOARD (May 2013), http://www.arb.ca.gov/ regact/2012/capandtrade12/linkfsor.pdf [https://perma.cc/MT7Y-3DLB] (discussing rationale for linking with Quebec and amendments to the state's regulations to facilitate the linkage); Facts about Livestock Methane Compliance Offset Credits under Investigation, CAL. AIR RESOURCES BOARD (Sept. 29, 2015), http://www.arb.ca.gov/cc/capandtrade/bos_dairy_ offset_investigation_faq.pdf [https://perma.cc/WJ3H-5Z29]. In February 2016, the agency issued its final determination, finding that the project was in compliance with Indiana law. Final Determination: Air Resources Board Compliance Offset Investigation Compliance Offset Protocol for Livestock Projects, CAL. AIR ResourCES BOARD (Feb. 10, 2016), https://www.arb.ca.gov/cc/capandtrade/offsets/bos_determination.pdf [https://perma.cc/ LY7W-FFQ7]. Holders of offset credits generated by the facility were unable to use the credits during the five-month investigation. Project Information: CAR1055, CLIMATE ACTION RES., https://thereserve2.apx.com/mymodule/reg/prjView.asp?id1=1055 [https://perma.cc/3BMC2HG2] (last visited Jan. 10, 2017).

169. The Quebec market requires offset projects to place $3 \%$ of the credits generated by the project into the buffer pool. See Kamala Harris, Memo to Cliff Rechtschaffen re Attorney General's Advice to the Governor Concerning Linkage of California and Quebec Cap-and-Trade Programs, ST. CAL. DEP’T JUST. 3 (Mar. 5, 2013), https://www.gov.ca.gov/docs/ AG_Letter_SB_1018.pdf [https://perma.cc/NVE8-59J5].

170. CAL. Gov’T CoDE $\S 12894$ (West, WestlawNext through Ch. 3 of 2017 Reg. Sess.). 
Similarly, the Clean Power Plan raised a host of policy considerations as California evaluated whether or not to participate in a trading-ready market system, highlighting the linkage policy questions that may arise when jurisdictions approach the prospect of market linkage with fundamentally different starting points. ${ }^{171}$ California does not need to pursue the tradingready approach in order to comply with the rule. The state measures approach outlined in the Clean Power Plan would allow the state to submit a plan that demonstrates a combination of state policies, including the Cap-andTrade Program, will result in the state's existing power plants meeting or exceeding their Clean Power Plan obligations. ${ }^{172}$

California's carbon market is more extensive than the Clean Power Plan. Section 111(d) of the Clean Air Act applies to existing sources stationary combustion turbines and electric generating steam units. This approach contrasts with California's multi-sectorial approach. Furthermore, the EPA interprets Section 111(d) to prohibit carbon offset credits, explicitly precludes offsets from state plans, and does not include a floor price or cost containment reserve. ${ }^{173}$

In August 2016, the California Air Resources Board submitted its proposed Clean Power Plan compliance plan, indicating that it would rely on instate policies for compliance and would not engage in any multi-state markets that may emerge under the rule. ${ }^{174}$ If California were to eventually pursue linkage with a Clean Power Plan market, it would presumably have to create a mechanism for excluding interaction between offset credits and the Clean Power Plan market. Otherwise, the offsets aspects of the California

171. Clean Power Plan Compliance Discussion Paper, CAL. Air REsourCEs BoARD (Sept. 2015), https://www.arb.ca.gov/cc/powerplants/meetings/2015whitepaper.pdf [https://perma. cc/YGH9-J759].

172. Tarr, supra note 103.

173. The Clean Power Plan does not restrict states from implementing cost containment mechanisms.

See Allison Donnelly et al., Regulating Greenhouse Gas Emissions under Section 111(D) of the Clean Air Act: Implications for Petroleum Refineries, DuKE NICHOLAS INST. FOR ENVTL. POL'y SOLUTIONS (June 2014), https://nicholasinstitute.duke.edu/sites/default/ files/publications/ni_wp_14-05_final.pdf [https://perma.cc/AFX5-PXJH]). Without a coordinated approach, however, a cost containment mechanism in one state would be ineffective if other states did not include similar provisions; the covered entities could purchase fungible allowances in the other states. See id. California may face a similar issue if Clean Power Plan allowances were fungible in the California system. See generally id.

174. California's Proposed Compliance Plan for the Federal Clean Power Plan, CAL. AIR RESOURCES BOARD (Aug. 5, 2016), https://www.arb.ca.gov/cc/powerplants/meetings/ 09222016/proposedplan.pdf [https://perma.cc/33QH-5K4X]. 
market would propagate into the Clean Power Plan market. California may also need to separate the electricity sector use of Clean Power Plan credits with the other sectors covered by the California market. ${ }^{175}$

Before deciding whether to alter the state market to allow existing power plants within the state to participate in a Clean Power Plan market, officials will need to weigh whether to scale back some of the state's policy goals in order to expand the scope of the market. For example, allowing power plants located within California to participate in a multi-state Clean Power Plan market could have a direct impact on the supply of allowances and the price of those allowances in the state's market. ${ }^{176}$ It may also mean ceding California's control over market design, as the Clean Power Plan establishes the rules for trading and California has little or no flexibility to alter those rules. By linking with the Clean Power Plan market, therefore, California may diminish its influence over future carbon market design.

Each of these points may complicate the ability to alter a jurisdiction's initial choices to foster linkage with other markets.

\section{B. Club Architecture}

A number of scholars and practitioners point to the concept of international clubs as a model for a bottom-up approach to reaching multilateral approaches to climate change mitigation. ${ }^{177}$ Clubs theory focuses on "goods that are

175. The EPA may develop existing source performance standards for other categories of sources. For example, in December 2010, the EPA entered into a settlement agreement requiring it to develop existing source performance standards for refineries and fossil fuel-fired power plants. See Refinery GHG Settlement Agreement, American Petroleum Institute v. E.P.A., No. 08-1277 (D.C. Cir. 2010), http://www2.epa.gov/sites/ production/files/2013-09/documents/refineryghgsettlement.pdf [https://perma.cc/8VHX52PY]; Boiler GHG Settlement Agreement, New York v. E.P.A., No. 06-1322 (D.C. Cir. 2010), http://www2.epa.gov/sites/production/files/2013-09/documents/boilerghgsettlement.pdf [https://perma.cc/8VHX-52PY]. The EPA missed the court-approved deadlines included in both agreements, and has not announced any official steps to develop $\mathrm{CO}_{2}$ performance standards for the refinery sector. For a discussion of potential regulatory approaches to the refining sector, see Donnelly et al., supra note 173.

176. If given the choice to sell allowances in either market, the profit maximizing business would be expected to choose the market offering the highest prices.

177. See, e.g., David G. Victor, Fragmented Carbon Markets and Reluctant Nations, in Architectures for AgreEment: AdDressing Global Climate Change in a PostKYOTO WORLD 144 (Joseph E. Aldy \& Robert N. Stavins, eds., 2007) (predicting that "what is likely to occur is not an integrated international emission trading system but, rather, a series of fragmented markets." For example, Victor describes a "zone" of countries that, "have the will and capability to create meaningful emission markets. These countries all have intense trading and investment relationships with each other. Their institutions tend to recognize each other - even to the point of allowing extraterritorial application of law. For these countries it is a relatively small step to imagine that they would extend their trading relationships to include a nascent currency of tradable emission credits. What defines the zone, however, is not their common interest in controlling emissions - indeed, their 
at least partially excludable (it is possible to exclude nonmembers from accessing them) and at least partially nonrivalrous (one individual's use of the good does not subtract from another individual's simultaneous use of that good) - [U]tility-maximizing actors have an incentive to share club goods with other actors and charge membership fees or tolls."178 Examples of climate mitigation activity through a club framework include: the Asia Pacific Partnership, an agreement of Pacific Rim countries to partner on clean energy research and development; the 17-member Major Emitters Forum on Energy and Climate Change, a club of 17 nations seeking to "help generate the political leadership necessary to achieve a successful outcome at the annual UN climate negotiations and advance the exploration of concrete initiatives and joint ventures that increase the supply of clean energy while cutting greenhouse gas emissions;" and the G8, which regularly focuses on climate change during its annual meetings. ${ }^{179}$ Carbon market participation may also be a price of entry for larger clubs. Eastern European states were required to participate in the EU ETS as a condition of European Union membership. ${ }^{180}$

The focus on clubs takes as a starting point the self-interested stance of governments and private firms and seeks to build upon those interests to develop an effective climate regime. As Keohane and Victor note, the UNFCCC process is a departure from the typical process for developing international regimes, as those regimes "often come about not through deliberate decision-making at one international conference, but rather emerge as a result of 'codifying informal rights and rules that have evolved

interests vary considerably as is evident when comparing the domestic policies in the EU, United States and Australia - but rather their institutional capabilities and the extent to which other members in the zone are confident in those capabilities.”).

178. Richard B. Stewart et al., Building Blocks for Global Climate Protection, 32 STAN. ENVTL. L.J. 341, 364 (June 2013).

179. Major Economies Held Dialogue for Paris Success, U.N. FrAMEWORK CONVENTION ON ClimATE CHANGE, http://newsroom.unfccc.int/lima/major-economiesheld-dialogue-for-paris-success/ [https://perma.cc/EF5Z-MZ2H] (last visited Mar. 27, 2017); see also Keohane \& Victor, supra note 164, at 12; Major Economies Forum on Energy and Climate, MAJOR ECONOMIES F., http://www.majoreconomiesforum.org [https://perma.cc/V56U-Z364] (last visited Oct. 25, 2015) ("The 17 major economies participating in the MEF are: Australia, Brazil, Canada, China, the European Union, France, Germany, India, Indonesia, Italy, Japan, Korea, Mexico, Russia, South Africa, the United Kingdom, and the United States.”).

180. Ranson \& Stavins, supra note 173 , at $1,7$. 
over time through a process of converging expectations or tacit bargaining.' That is, they emerge in path-dependent, historically-shaped ways."181

Self-interest may take many forms. Countries may already work together on multilateral goals, such as trade liberalization or monetary policy. The existing institutions and familiarity may lend themselves to incorporating climate mitigation into the relationship. A desire for legitimacy may also spur interest in club membership. Recent economic powerhouses such as China, or emerging economies such as India or Brazil, may see benefits to participation in multilateral climate mitigation efforts.

Self-interest may also arise from a desire to address public health impacts of other air pollutants, with climate mitigation as a byproduct. Alternatively, the self-interest may explicitly include addressing climate change. Once a jurisdiction makes the unilateral decision to implement GHG reduction measures, government officials may seek to lower compliance costs for their covered sectors by allowing access to emission reduction options available in a larger market system. Nations seeking to address climate change may also recognize that multilateral action is necessary to lower global emissions, thus leading that nation to participate in an international market even if doing so requires compromise on policy objectives.

Club approaches to multilateral market-based climate policy may evolve via different pathways. A clubs approach to climate mitigation could emerge under existing international frameworks, such as regional trade agreements or other existing international frameworks. ${ }^{182} \mathrm{~A}$ clubs approach could also include firm-based cooperation in addition to, or in lieu of, governmental cooperation. ${ }^{183}$ For example, Stewart, et al. propose three "building blocks" to achieve multilateral action on climate change: a club strategy, a linkage strategy, and a dominant market participant strategy. ${ }^{184}$ The authors note that meaningful climate mitigation may occur through cooperation at the governmental level or through firms with a dominant market position and focus on the many forms of cooperation and linkage possible through existing institutions. ${ }^{185}$ Market-based approaches are not central to Stewart, et al.'s building blocks approach, but the authors do cite linking markets through

181. Keohane \& Victor, supra note 164, at 3 (quoting Oran R. Young, GLOBAL GOVERNANCE: DRAWING INSIGHTS FROM THE ENVIRONMENTAL EXPERIENCE 10 (1997)).

182. See, e.g., Zaman \& Hedley, supra note 173, at 16-18 (noting the potential for, and barriers to, carbon market development pursuant to the Trans-Pacific Partnership or World Trade Organization).

183. Stewart et al., supra note 32, at 3-4.

184. Id. Other scholars have proposed a "building blocks" framework for global climate mitigation measures. See e.g., Robert Falkner et al., International Climate Policy After Copenhagen: Towards a “Building Blocks” Approach, 1 GLOBAL POL’y 252, 253258 (Oct. 2010).

185. Stewart et al., 120 ClimATiC CHANGE, supra note 32, at 3-4. 
a club framework among the options to implement the building blocks approach. ${ }^{186}$ Furthermore, the building block strategy includes bilateral and regional air quality programs among the options for leveraging existing institutions "to provide the basis and create support for future regulatory recognition, offset trading, and, eventually, full greenhouse gas emission trading programs.”187

A third approach to club-based GHG mitigation measures could focus specifically on the development of carbon markets. For example, Green, et al. focus directly on an incremental approach to market linkage, concentrating first on developed countries due to the higher likelihood that they will have "robust regulatory systems to support successful implementation, monitoring and compliance mechanisms required for a functional system" and "the differences in marginal costs of abatement are likely to be relatively small, wealth transfers will be correspondingly low, relative to total allowance value." 188 The authors suggest minimizing indirect linkages due to the political uncertainty associated with the absence of explicit agreement, and ensuring direct coordination among linking jurisdictions to ensure consistency in market design. ${ }^{189}$

\section{OPTIONS FOR STREAMLINING MARKET LINKAGE}

Club architecture offers the potential to streamline policy choices and may lead to long-term stability if the club partners have an interest in maintaining positive relations or seek to achieve multiple policy objects through the club. Club participants may also proactively address market design concerns presented by bottom-up strategies, such as protecting against forum shopping and leakage, and bolstering market stability by anticipating the prospect that one or more club members may withdraw. 190

Path dependency barriers to market linkage may persist, however, as market implementation may realign political constituencies. These concerns are

\footnotetext{
186. Stewart et al., supra note 178, at 374; id. at 344 (noting that the linkage element in Stewart's proposed building blocks refers to "leverage[ing] existing transnational organizations with missions other than climate protection,” rather than linked carbon markets.).

187. Id. at 375-76.

188. Green et al., supra note 148, at 1066; see also Keohane et al., supra note 12, at

189. Green et al., supra note 148, at 1066-67.

190. William A. Pizer \& Andrew J. Yates, Terminating Links between Emission Trading Programs, RESOURCES FOR THE FUTURE 2-3 (Aug. 2014), http://www.rff.org/files/sharepoint/ WorkImages/Download/RFF-DP-14-28.pdf [https://perma.cc/ZU4G-3MF8].
} 3. 
not insurmountable. Emissions markets have undergone adjustments in the past, and future adjustments are likely. ${ }^{191}$ Yet, the need to make significant changes to facilitate market linkage may disincentivize linkage with certain partners, fostering a more balkanized, less efficient approach to emissions reductions than would otherwise occur if market participants were subject to the same set of rules or engaged in market design at the same time.

The following subparts discuss three strategies to standardize design choices, thereby reducing path dependency barriers to market linkage. First, linkage may occur through a coordinated approach involving simultaneous development of carbon markets. Second, a jurisdiction may unilaterally design its market approach to accommodate future linkage, providing a clear set of market characteristics that future linking partners must include in order to facilitate linkage. Under this strategy, a dominant jurisdiction sets the terms for future market linkage. Third, jurisdictions may identify a standardized approach to key market design choices through a common elements framework such as the "trading-ready" approaches embedded in the U.S. EPA's Clean Power Plan rule. Each approach would facilitate full fungibility of emission allowances or offset credits. ${ }^{192}$

\section{A. Coordinated Design Strategy}

The California and Quebec experience is an example of the benefits of a coordinated design strategy. The Western Climate Initiative (WCI) process allowed both jurisdictions to jointly contemplate market linkage while developing initial regulations establishing their respective markets. ${ }^{193}$ As a result, each jurisdiction included similar provisions that streamlined the linkage process. ${ }^{194}$

In addition to ex ante incorporation of linkage procedures, the coordinated market design approach minimizes path dependency obstacles for initial linkage. Although officials in California and Quebec did not make identical

191. Newell et al., supra note 40.

192. This paper does not discuss other alternatives for market interaction, such as implementing emission allowance exchange rates. For a discussion of emission allowance exchange rates, see O’Connell, supra note 173, at 371-72.

193. WCI Design Recommendations, supra note 99, at 1, 13, 15-17; see, e.g., CAL. Code Regs. tit. 17, § 95941 (WestlawNext through 3/10/17 Register 2017, No. 10) (establishing procedures for market linkage); see also CAL. GOv’T CODE $§ 12894$ (West, WestlawNext through Ch. 3 of 2017 Reg. Sess.); CAL. Air RESOURCES BoARD, supra note 174.

194. For example, the two market systems included identical restrictions on the percentage of offsets that a covered entity may submit in a compliance period, see Katherine Hsia-Kiung et al., Carbon Market California: A Comprehensive Analysis of the Golden State's Cap-and-Trade Program, ENVTL. DEF. Fund 18 (2014), https://www.edf.org/sites/default/files/ content/carbon-market-california-year_two.pdf [https://perma.cc/PW6W-LC9T]. 
market design choices, the ongoing WCI partnership allowed them to coordinate many of the provisions and understand the key differences that would need to be addressed to facilitate linkage. For example, the different approaches to offsets liability did not prohibit linkage because each approach addresses concerns about the environmental integrity of the compliance instruments. Officials determined that the two approaches - the offsets reserve pool in Quebec and buyer liability in California-were able to operate in parallel. Similarly, Ontario's participation in the WCI should similarly streamline the expansion of the carbon market.

The coordinated approach allows prospective market partners to identify the key market design decision-points at the outset, work together to evaluate market design options, and make regulatory decisions in their respective jurisdictions with an understanding of how those actions relate to actions taken by their prospective linking partners. This approach allows the common design choices to emerge among the partners, minimizing future hurdles with the linking process.

\section{B. Dominant Actor Strategy}

The EU ETS and the California Cap-and-Trade Program have emerged as desirable linking partners, situating the two programs as dominant actors in the arena of market linkage. ${ }^{195}$ Both already operate as linked systems, and both have expressed the desire to link with additional jurisdictions. The EU market is by far the world's largest carbon market. ${ }^{196}$ Also, as the first multinational carbon market, the EU system has identified and addressed market design issues, such as allowance allocation, verifiable emissions data, and continuity between design periods. ${ }^{197}$ The California and Quebec market is the only international carbon market consisting of subnational entities, and California actively seeks relationships with other subnational

195. This subsection borrows from Stewart et al.’s discussion of dominant firms. Stewart et al., supra note 178, at 345 ("Where dominant public or private actors enjoy sufficient economic, strategic, or reputational gain from being a first mover in adopting regulatory or market standards, they may act unilaterally to induce others in the sector to follow suit (for example, the expansion of the European Union Aviation directive to foreign airlines). In appropriate contexts, dominant actors may have incentives to adopt measures that have the purpose or effect of reducing greenhouse gas emissions.”).

196. Newell et al., supra note 40, at 126-27.

197. A. Denny Ellerman \& Barbara K. Buchner, The European Union Emissions Trading Scheme: Origins, Allocation, and Early Results, 1 REV. ENVTL. ECON. \& POL’y 66, 66, 70 (2007). 
actors with which it may link markets or from which it may accept offset credits in the future. ${ }^{198}$ Furthermore, both the EU and California are important economic actors and jurisdictions considering carbon market linkage may hope to realize benefits beyond those associated directly with market-based climate change mitigation. ${ }^{199}$

The influence of the EU ETS and the California market is important for three reasons. First, unlike the period when the two markets were under development, models for carbon market design now exist. Jurisdictions considering market-based climate policy are not starting from scratch. Second, government officials undertaking efforts to design new carbon markets may do so with an eye toward linkage and identify prospective linking partners early in the design process. The design features necessary to facilitate market linkage are evident in the existing market format. The announced intentions by New Zealand, South Korea, and Australia to link with the EU ETS all provide examples of this approach. Third, the jurisdictions with established markets attracting attention among potential partner jurisdictions may set the terms for market design.

The 2015 announcement by New York Governor Andrew Cuomo that his administration intends to "work with California and other jurisdictions to develop a broad North American carbon market” may prove more challenging. ${ }^{200}$ Both RGGI, of which New York is a participant, and California have successful track records. Yet, the markets differ from one another in important ways. First, California's market covers multiple sectors of the economy while RGGI only covers the electricity sector. Second, the California regulations include market oversight provisions, including tracking ownership of allowances and imposing holding limits that restrict the number of allowances a market participant may hold at any given time, requirements that do not apply to RGGI market participants. ${ }^{201}$ Third, the emissions cap and the treatment of offsets also differ between the two markets. The different sectoral coverage would not prevent linkage, as regulators could adjust the overall emissions cap for the linked market based on the scope

198. For a summary of current national and subnational carbon markets in place across the globe, see Brewer et al., supra note 143.

199. Stewart et al., supra note 178, at 374.

200. Press Release, State of N.Y., Governor Cuomo, Joined by Vice President Gore, Announces New Actions to Reduce Greenhouse Gas Emissions and Lead Nation on Climate Change (Oct. 8, 2015), http://www3.dps.ny.gov/pscweb/WebFileRoom.nsf/Web/1BC8381FF19B 584485257ED80070792B/\$File/gov\%2010.8.15.pdf?OpenElement [https://perma.cc/ULA9WLLZ].

201. See, e.g., Market Program Monitoring, CAL. AIR ResourCes BOARD, http://www. arb.ca.gov/cc/capandtrade/marketmonitoring/marketmonitoring.htm [https://perma.cc/ PV6U-8AW5] (last visited Mar. 14, 2017). 
of coverage. The other differences, however, may undermine design choices in one market or the other.

The distinctions between the California and RGGI markets highlight the potential difficulty with established markets that develop independently then seek to link at a later date. It is not clear whether either state would cede the role of dominant market actor to the other. Market changes by either or both jurisdictions would affect the market participants within their borders, as well as their existing linking partners. Officials representing New York and California may determine that the dominant actor model offers the least disruptive approach for the majority of market participants. Alternatively, the two states may forgo attempts to streamline the linkage process in favor of a more robust reorganization of market design choices through a coordinated approach. ${ }^{202}$

\section{Common Elements Strategy}

The previous two strategies provide linkage options when jurisdictions have identified prospective partners. In instances where a jurisdiction is establishing a market and anticipates future linkage with unidentified partners, a "common elements" strategy similar to the Clean Power Plan tradingready concept may provide a useful model. ${ }^{203}$ States adopting the tradingready approach would allow diffuse markets to emerge if power plant operators determined it was in their interest to participate in such a market. The approach would not require state regulators to design the markets or endorse participation in the markets.

Two existing models provided support for the Clean Power Plan tradingready option. First, many state-level renewable portfolio standards (RPSs) operate under a similar "common elements" framework. These programs identify a percentage of renewable energy that retail electricity providers must include in their respective generation mix. Compliance entities may satisfy their obligations by either investing directly in qualifying renewable

202. This article does not provide an exhaustive description of linkage options. For example, New York and California could consider a less centralized approach to market linkage through an exchange rate model. See Bodansky, supra note 88, at 3.

203. This article opts for the common elements terminology rather than tradingready because additional steps beyond simply incorporating common market provisions may be necessary to facilitate trading. See Monast et al., supra note 114. 
facilities or submit renewable energy credits (RECs) that represent onemegawatt hour of qualifying renewable energy generation. ${ }^{204}$

Multistate REC markets have emerged when states incorporate similar definitions for tradable compliance instruments and allow entities to generate those compliance instruments beyond the state's borders. ${ }^{205}$ These jurisdictions often allow covered entities to utilize credits that originate either inside or outside the state, so long as they meet criteria specified by the state of compliance. ${ }^{206}$ In addition to defining the RECs and what constitutes a renewable energy facility, state RPSs designate approved tracking systems to protect against double counting. This model allows interstate REC trading without requiring perfect alignment of state RPS policies. For example, some include a broad suite of generation options under the definition of "renewable," while others are more restrictive. ${ }^{207}$ Similarly, some states include specific requirements for certain generation options, such as minimum percentages of solar generation or, in the case of North Carolina, requirements to purchase electricity generated by swine and poultry waste. ${ }^{208}$ As long as a renewable energy facility satisfies the criteria of qualifying generation under multiple state RPS policies, the REC may trade among the states without requiring those states to enter into agreements with one another.

The RGGI system offers another model that informs the trading-ready concept, as it operates as a linked market rather than a single, top-down system. In order to avoid potential Compact Clause challenges, the state negotiators developed a model rule specifying the program's components, including emission caps, permits and allowance allocations, tracking system requirements, and rules governing trading. ${ }^{209}$ The states participating in RGGI each implemented their own legislation and regulations to implement the model rule provisions, thereby creating a regional market based on a

204. In some states, energy efficiency credits can count toward RPS requirements. See, e.g., N.C. GEN. STAT. § 62-133.8(b)-(i) (LexisAdvance through session Laws 2016-

Session, and Session Laws 2017-2 of the 2017 Regular Session).

205. Jan Hamrin, REC Definitions and Tracking Mechanisms Used by State RPS Programs, CLEAN ENERGY STATES AllianCE (June 2014), http://www.cesa.org/assets/2014Files/RECs-Attribute-Definitions-Hamrin-June-2014.pdf [https://perma.cc/NTM9-99K4].

206. See Monast et al., supra note 114 .

207. Warren Leon et al., Clean Energy Champions: The Importance of State Programs and Policies, Clean EnERgy States Alliance (June 2015), http://www.cesa.org/assets/ 2015-Files/Clean-Energy-Champions.pdf [https://perma.cc/7EST-Q2H2].

208. Renewable Energy and Energy Efficiency Portfolio Standard, ENERGy.gov, https://energy.gov/savings/renewable-energy-and-energy-efficiency-portfolio-standard [https://perma.cc/95VF-MZAR] (last visited Mar. 14, 2017).

209. Model Rule Part XX CO2 Budget Trading Program, Regional GreEnHouse GAS InITIATIVE (Dec. 23, 2013), http://rggi.org/docs/ProgramReview/_FinalProgramReview Materials/Model_Rule_FINAL.pdf [https://perma.cc/76FF-9EKW]. 
common set of rules rather than a single unified program. ${ }^{210}$ The RGGI created its own nonprofit to facilitate allowance auctions and monitor compliance. ${ }^{211}$ However, at its core, RGGI is an example of a tradingready $\mathrm{CO}_{2}$ mitigation program that imposes emissions limits on a specified group of sources, establishes emission allowances to comply with the emission caps, and allows interstate trading of those allowances. ${ }^{212}$

Policymakers seeking to standardize key market design choices through a common elements strategy may draw from three sources. First, jurisdictions anticipating future market linkage may identify the criteria necessary to facilitate market linkage by conducting a general survey of design approaches underlying existing carbon markets. The precedent for linking carbon markets, albeit still relatively limited, provides insights into the compatibility of design elements and the options for aligning dissimilar market provisions. At minimum, the common aspects of existing carbon trading include a cap on emissions, a legally-binding obligation for specific sources of GHGs emissions, identification of the tradable compliance instruments, and measures to ensure that the tradable instruments meet the legal requirements and protect against double-counting.

Second, linkage criteria spelled out by California regulations or by European Union Directives may provide additional guidance for jurisdictions seeking to align carbon market design choices through a common elements approach. ${ }^{213}$ In addition to the minimal elements necessary for market linkage identified above, additional alignment may include common protocols for offset credits and similar emission stringency. ${ }^{214}$

Third, government officials tasked with designing a market while preserving the option for future linkage may focus particular attention on

210. See, e.g., Conn. Gen. Stat. Ann. 22a-200c (West, WestlawNext through General Statutes of Connecticut, Revision of 1958, Revised to January 1, 2017); CoNN. AgenCIEs Regs. § 22a-174-31(3) (WestlawNext through Conn. L.J. through 3/21/2017); DEL. CODE ANN. tit. 7, § 6043 (LexisAdvance through ).

211. Mission Statement, REGIONAL GREENHOUSE GAS INITIATIVE, https://www.rggi.org/rggi [https://perma.cc/BG5Y-M9LX] (last visited Jan. 6, 2017).

212. Susan F. Tierney et al., RGGI and CO2 Emissions Trading Under the Clean Power Plan: Options for Trading Among Generating Units in RGGI and Other States, ANALYSIS GROUP, INC. (July 12, 2016), http://www.eenews.net/assets/2016/07/12/document _cw_01.pdf [https://perma.cc/ULB4-5GC8].

213. CAL. GOV’T CODE § 12894 (West, WestlawNext through Ch. 3 of 2017 Reg. Sess.); Council Directive 2009/29/EC, 2009 O.J. (L. 140/63); Climate Action: International Carbon Market, EUR. COMMISSION, https://ec.europa.eu/clima/policies/ets/markets_en [https:// perma.cc/4YVL-LJLK] (last updated July 1, 2016).

214. EUR. COMMISSION, supra note 213. 
the potential for market features to affect design choices in other markets. Some market components may propagate into linked markets, while others may affect the function and impacts of the domestic market but not directly affect other markets through linkage. For example, choices between allocating allowances for free, auctioning allowances, or both, would have domestic impacts. ${ }^{215}$ Furthermore, if jurisdictions choose to allocate allowances, they have a choice regarding which entities receive the allowances and what they may do with the proceeds. ${ }^{216}$ Examples include distribution based on historic electricity generation, generation based on electricity output, or allocation to distribution companies rather than electricity generators. ${ }^{217}$ Similarly, jurisdictions that auction allowances may choose to use the revenue to implement complementary policies such as energy efficiency programs, ${ }^{218}$ refund the value back to consumers, ${ }^{219}$ or incorporate the revenue into the government's general operations funds. ${ }^{220}$ While these choices affect the economic impacts of the program, ${ }^{221}$ different approaches to entering allowances into the marketplace would not affect the function of markets in other jurisdictions with which the jurisdiction may link.

In contrast, other design elements such as the stringency of the emissions cap, cost containment mechanisms, and acceptance of offsets would propagate into other markets. A stringent emissions cap in one jurisdiction and a less stringent cap in another would cause overall prices to decrease as the lax cap would mean more allowances in the marketplace and thus affect the supply and demand ratio.

Cost containment provisions come in many forms. Jurisdictions may implement a price ceiling, a price floor, or an allowance reserve to make

215. Participating in the EU ETS, U.K. DePT. Bus. ENERGy, \& INDUS. STRATEGY (Jan. 22, 2013), https://www.gov.uk/guidance/participating-in-the-eu-ets [https://perma.cc/ YN7J-UM6R].

216. James Nachbaur \& Tiffany Roberts, Evaluating the Policy Trade-offs in ARB's Cap-and-Trade Program, CAL. LEGIS. ANALYST's OFF. (Feb. 9, 2012), http://www.lao.ca.gov/ reports/2012/rsrc/cap-and-trade/cap-and-trade-020912.aspx [https://perma.cc/SE5H-P6HX].

217. GHG Abate Measures, Envtl. Protection Agency on Allowance Allocation Proposed Rule Technical Support Document, U.S. EnvTL. Protection AgEncy OfF. Air \& RADIATION (June 10, 2014), https://www.epa.gov/sites/production/files/2014-06/documents/ 20140602tsd-ghg-abatement-measures.pdf [https://perma.cc/DS4K-GG82].

218. Why Energy Efficiency?, REGIONAL GREENHOUSE GAS INITIATIVE, https://www. rggi.org/rggi_benefits/why_efficiency [https://perma.cc/BR5P-ZYQM] (last visited Jan. 6, 2017).

219. Anne C. Mulkern, Gov. Brown Proposes to Borrow $\$ 500 M$ from Cap-andTrade Revenue, E\&E NEws (May 15, 2013), http://www.eenews.net/stories/1059981189 [https://perma.cc/JV43-A9RZ].

220. Mulkern, supra note 219.

221. Industry Windfall Profits from Europe's Carbon Market, CARBON MKT. WATCH 2-5 (Mar. 14, 2016), http://carbonmarketwatch.org/wp-content/uploads/2016/03/Policybrief_Industry-windfall-profits-from-Europe\%E2\%80\%99s_web_final-1.pdf [https://perma. cc/C4Z4-YL5A]. 
additional allowances available at a specific price. Market linkage between a jurisdiction with cost containment provisions and one without the same provisions would affect prices in both markets. For example, if State A has a price floor and State B does not, a market actor could potentially purchase cheaper allowances in State B and submit them for compliance in State A. The price floor would no longer prevent allowance prices from dropping beneath the floor. ${ }^{222}$ Market oversight, including approaches to foster transparency regarding what is trading and where, access to market information such as trading volume and prices, and control against financial market manipulation could also affect market operations in linked jurisdictions. ${ }^{223}$

The focus on propagation may minimize the potential for investmentbased path dependency while also allowing government officials to make political compromises for the non-propagating market aspects. As a threshold matter, decisions regarding what instruments may trade and the mechanisms for tracking the instruments to ensure their integrity and protect against fraud are necessary elements to facilitate linkage with any existing carbon market system. Furthermore, accounting rules establishing the framework for measuring emissions and evaluating the performance of the market are key aspects of an effecting carbon market. The UNFCCC process has made progress on measurement, reporting, and verification provisions, but the prospect of international monitoring remains controversial. ${ }^{224}$ Effective enforcement is a further necessary component to ensure the integrity of a market system. Without capable government oversight, the market may not achieve the environmental goals for which it was created due to fraud on the part of market participants.

As the California and Quebec market linkage demonstrates, absolute alignment is not necessary to facilitate linkage. Addressing those aspects that may propagate, and thus affect the market value or political compromises in other jurisdictions, however, might be necessary before linkage may occur.

222. Alan Durning \& Yoram Bauman, 17 Things to Know About California's Carbon Cap: The Golden State Rules, SIGHTLINE INST. (May 22, 2014), http://www.sightline.org/ 2014/05/22/17-things-to-know-about-californias-carbon-cap/ [https://perma.cc/R8ZQ-UYPV].

223. Ranson \& Stavins, Post-Durban Climate Policy Architecture Based On Linkage Of Cap-And-Trade Systems, supra note 148, at 410.

224. David Hunter, Implications of the Copenhagen Accord for Global Climate Governance, 10 SustainABLE DEV. L. \& POL'y 4, 8 (2010). 


\section{CONCLUSION}

The shift from a centralized, top-down approach to a diffuse, bottomup approach to carbon market implementation has important implications for the effectiveness, cost, and complexity of mitigation efforts. The ultimate impact of these diffuse steps depends on whether or not they contribute to the long-term development of a broad, multilateral strategy capable of aggressively reducing global emissions. Market linkage and clubs architecture offer promising pathways to move from incremental to comprehensive measures, but the evolutionary process will depend upon careful initial policy design that streamlines multijurisdictional cooperation. Existing experiences with national and subnational carbon market linkage, and the common elements strategy embedded in the U.S. EPA's Clean Power Plan, provide import lessons to help facilitate that movement toward a global solution to a global commons problem. 